\title{
CONSIDERACIONES SOBRE EL PRINCIPIO DE LEGALIDAD PENAL EN LA JURISPRUDENCIA DE LA CORTE INTERAMERICANA DE DERECHOS HUMANOS
}

\author{
CONSIDERATIONS ON THE PRINCIPLE OF CRIMINAL \\ LEGALITY IN JURISPRUDENCE OF THE INTER-AMERICAN \\ COURT OF HUMAN RIGHTS
}

\author{
Sergio GARCÍA RAMÍREZ* \\ Julieta MORALES SÁNCHEZ**
}

\begin{abstract}
RESUMEN: En el marco del Estado constitucional y democrático de derecho, es comúnmente aceptado que los actos del poder público se hallan gobernados por la ley. Sin embargo, actualmente se habla de una crisis o colapso en la concepción tradicional del principio de legalidad. El derecho internacional de los derechos humanos ha introducido cambios apreciables en esta materia. El principio de legalidad, en general, y de legalidad penal, en particular, ha sido ampliamente interpretado por la Corte Interamericana de Derechos Humanos. Se analiza el principio de legalidad desde la perspectiva del derecho internacional de los derechos humanos y dentro del sistema interamericano de protección de derechos humanos. Después se centra el estudio en el principio de legalidad penal y la interpretación que de éste ha hecho la Corte Interamericana de Derechos Humanos.
\end{abstract}

Palabras claves: Principio de legalidad penal, derecho internacional de los derechos humanos, Corte Interamericana de Derechos Humanos, legalidad formal y legalidad material.
ABSTRACT: Under the constitutional and democratic State of law it is widely accepted that the acts of state are ruled by law. However, nowadays it is said that the traditional conception of the principle of legality is passing through a crisis or even in danger of collapsing. The International human rights law has introduced significant changes in this area. The principle of legality in general, and particularly, the principle of criminal legality have been thoroughly interpreted by the Inter-American Court of Human Rights. Throughout the first part of this article the principle of legality is carefully analyzed from the perspective of international human rights law and within the Inter-American Human Rights System. The second section focuses on the study of the principle of criminal legality and its interpretation by the Inter-American Court of Human Rights.

Descriptors: principle of criminal legality, International human rights law, Inter-American Court of Human Rights, formal legality and legitimacy.

* Investigador en el Instituto de Investigaciones Jurídicas de la UNAM.

** Profesora de la Facultad de la UNAM. 


\section{PlanteAmiento E INTRODUCCIÓN}

En la persistente dialéctica entre el poder, por una parte, y la libertad, por la otra, que se refleja en el encuentro - histórico, actual y futuro- entre la autoridad y el individuo, se localiza el tema de la "legalidad" como cauce para el desempeño de la autoridad y garantía para el desenvolvimiento del ser humano. En este punto de contacto y deslinde se han enfrentado las ideas y las tareas.

Hoy, el poder - la autoridad - acepta el imperio de la legalidad, inicialmente rechazado o resistido, pero pugna por la "moderación", que se suele presentar como requerimiento colectivo: ejercicio "razonable" de la discrecionalidad, restricciones, limitaciones, suspensiones en el ámbito de los derechos y las libertades. El individuo — bajo el doble título de ser humano y ciudadano - reclama la mayor latitud posible para el goce y el ejercicio de la libertad, que aloja el creciente conjunto de sus derechos, y pugna por datos de contención que sometan el desempeño del poder.

Es aquí donde se instala la "legalidad" y se establecen —al amparo de los progresos de la democracia y los derechos humanos - los "controles sobre la autoridad" y los "límites de la libertad". Unos y otros residen en la ley, es decir, en la norma que acoge por diversas vías — que no es del caso examinar ahora - la voluntad general, nacional, popular - como se prefiera-, que dispondrá hasta dónde puede llegar y cómo debe actuar el brazo del poder, y cuál es el ámbito previsto para el curso libre y responsable de la libertad.

Las expresiones de esta dialéctica se han acumulado en la historia particular de las comunidades nacionales, expuesta en la Constitución y la legislación, la costumbre y la jurisprudencia. En una etapa posterior, la dialéctica cobró nuevos territorios: llegó, como cuestión central, al espacio internacional, donde se recoge una tradición jurídica que numerosos Estados comparten. De esta suerte, el derecho internacional de los derechos humanos ha construido estatutos que definen, a su manera, los espacios de la libertad y los controles sobre la autoridad. Pretenden ser el "reducto legal de la legitimidad". Se acomodan en normas y decisiones del amplio conjunto de instancias que componen una "red internacional" cada vez más influyente y compleja.

Ahora bien, hay espacios de encuentro entre la autoridad y el individuo, es decir, entre el poder y la libertad, que ofrecen mayores riesgos en tanto suponen el despliegue del poder más intenso, con el vasto arsenal de 
instrumentos que éste puede asumir - y de "razones" que suele invocar para ejercerlo-, y el peligro más grave para las libertades y los derecho individuales, sujetos a compresión, reducción o retroceso. En esos espacios destaca, evidentemente, el desempeño punitivo del Estado. Se ha observado en la constante experiencia de los pueblos, en la literatura clásica ${ }^{1}$ y en la reflexión contemporánea. ${ }^{2}$

El desempeño punitivo se cifra en la definición de los delitos, las consecuencias jurídicas de la conducta ilícita, la "selección" de los delincuentes, el método (proceso) para aplicar esas consecuencias a los responsables de aquellas conductas, y la ejecución de las sanciones. ${ }^{3}$ En este extremo descuella, como en ningún otro, la importancia de la legalidad —un principio, una regla, una garantía, una cultura - para el imperio de la libertad y la subsistencia de la democracia.

En este trabajo nos proponemos exponer la creciente importancia que ha tenido el tema de la legalidad en la versión —o vertiente - interamericana del derecho internacional de los derechos humanos, desde la perspectiva del órgano instituido para interpretar y aplicar el corpus juris de la materia. De esto se ha ocupado la Corte Interamericana de Derechos Humanos (CorteIDH o Corte) en tres décadas de actividad creciente, a través de una jurisprudencia que precisa el perfil y asegura la persistencia y el desarrollo

1 Dijo Beccaria: en caso de haber una exacta y universal escala de las penas y de los delitos, tendríamos una común y probable medida de los grados de tiranía y de libertad y del fondo de humanidad o de malicia, de todas las naciones". De los delitos y de las penas, trad. Juan Antonio de las Casas, México, Fondo de Cultura Económica, 2006, p. 226, y observó Lardizábal: "nada interesa más a una nación que el tener buenas leyes criminales, porque de ellas depende su libertad civil y en buena medida la buena constitución y seguridad del Estado". Discurso sobre las penas contraido a las leyes criminales de España, para su reforma, México, Porrúa, 1a. ed., facsimilar, 1982, p. III

2 "Es en el campo penal donde se manifiesta en forma más ostensible el carácter democrático o antidemocrático de una Constitución". Bettiol, Giuseppe, Derecho penal. Parte general, trad. José León Pagano, Bogotá, Temis, 1965, p. 28. El sistema penal dice Jescheck - limita la libertad, pero también "crea libertad". Cfr. Tratado de Derecho penal. Parte general, trad. S. Mir Puig y F. Muñoz Conde, Barcelona, Bosch, 1982, p. 5. El derecho penal se halla simultáneamente legitimado y limitado por los derechos del hombre. Cfr. "Les processus d'interaction", Les chemins de l'harmonisation pénale/Harmonising Criminal Law, Delmas-Marty, Mireille, Pieth, Mark et Sieber, Ulbrich (dirs.), Juliette Lelieur (coord.), Societé de Législation Comparée, Paris, 2008, p. 429.

3 Cfr. García Ramírez, Sergio, "Panorama de la justicia penal", La ciencia del derecho durante el siglo XX, México, UNAM, Instituto de Investigaciones Jurídicas, 1998, pp. 718 y ss. 
de la legalidad, jurisprudencia cada vez mejor comprendida y recibida en el ordenamiento - y la práctica - de los Estados que concurren al sistema interamericano. ${ }^{4}$

Tomando en cuenta la naturaleza de los "casos" sometidos a esa Corte - hipótesis de violencia extrema-, la jurisprudencia ha operado con especial acento en los temas que antes mencionamos: tipificación, penalización, enjuiciamiento, ejecución, acentuando las exigencias de la legalidad en todos los supuestos.

Existe, pues, un tratamiento constante y cada vez más fino de los temas de legalidad en la jurisprudencia interamericana, con la mirada puesta, desde luego, donde es indispensable cifrarla: en la tutela concreta de los derechos y libertades de las personas, sin que la seguridad de unos mine la seguridad de todos. Es así que la jurisprudencia instalada en casos originalmente penales - aunque la Corte no es, obviamente, un tribunal penal — ha provisto al derecho interamericano de los derechos humanos, y por este medio al derecho interno de los Estados americanos, con criterios que contribuyen a los fines del sistema de protección.

Así, en el curso de este trabajo examinaremos el planteamiento y la tesis que ahora adelantamos, a través de los diversos temas abarcados por la jurisprudencia del Tribunal interamericano. Se trata de una jurisprudencia que concurre a aliviar - pero no a disipar - el temor que prevalece entre muchos penalistas: erosión del derecho penal liberal por obra de las corrientes antidemocráticas que esgrimen la seguridad pública $-\mathrm{O}$ la seguridad nacional - como argumento del autoritarismo; (falso) dilema entre crime control y due process,${ }^{5}$ habida cuenta de que "el proceso

4 A este respecto, $c f r$, por ejemplo, García-Sayán, Diego, “Una viva interacción: Corte Interamericana y tribunales internos", en Varios, La Corte Interamericana de Derechos Humanos. Un cuarto de siglo. 1979-2004, Corte Interamericana de Derechos Humanos, San José, C. R., 2005, pp. 323 y ss., y Abreu Burelli, Alirio, "Jurisprudencia de la Corte Interamericana de Derechos Humanos”, en id., pp. 87 y ss. En nuestra bibliografía más reciente, véase García Ramírez y Castañeda Hernández, Mireya (coords.), Recepción nacional del Derecho internacional de los derechos humanos y admisión de la competencia contenciosa de la Corte Interamericana, México, UNAM, Instituto de Investigaciones Jurídicas/Secretaría de Relaciones Exteriores, 2009.

5 Cfr. Delmas-Marty, "Discurso", Panorama internacional sobre justicia penal. Proceso penal y justicia penal internacional. Culturas y sistemas jurídicos comparados/ Séptimas Jornadas sobre Justicia Penal, México, UNAM, Instituto de Investigaciones Jurídicas, México, 2007, p. XIII; id., Procesos penales de Europa (Alemania, Inglaterra y País de Gales, Bélgica, Francia, Italia), trad. Pablo Morenilla Allard, Zaragoza, Eijus, 2000 , pp. 40 y 41. 
penal es probablemente el mejor campo de pruebas de la eficacia de los derechos fundamentales en un ordenamiento jurídico". ${ }^{6}$

Por supuesto, no pretendemos analizar aquí el concepto de legalidad penal, ampliamente regulado por la ley y examinado por la doctrina y la jurisprudencia. Nos proponemos dar cuenta de los criterios sustentados a este respecto por la Corte Interamericana de Derechos Humanos, que ha hecho aportaciones de suma importancia a este tema, tanto en lo que toca al principio de legalidad en general, como en lo que atañe a la legalidad en materia penal, que es el tema central de este trabajo.

Revisaremos las expresiones e implicaciones de la legalidad penal y mencionaremos los problemas que persisten en este campo. Por supuesto, se trata de una materia debatible $-\mathrm{o}$ bien, de un conjunto de temas controvertibles-, que conviene analizar con objetividad, dentro de su circunstancia, ponderando la evolución de la jurisprudencia y sus aportaciones a la tutela de los derechos humanos. Subsisten —así se verá en el curso de la presente exposición-zonas de duda o incertidumbre, "retos y desafíos", como se suele decir. Obviamente, la tarea no ha concluido, pero ha avanzado de manera apreciable. ${ }^{7}$ La Corte Interamericana ha examinado aspectos muy relevantes del principio de legalidad penal y ha establecido, por este medio, directrices útiles para la revisión del derecho interno.

\section{EL PRINCIPIO DE LEGALIDAD Y EL DERECHO INTERNACIONAL DE LOS DERECHOS HUMANOS}

\section{Legalidad y legitimidad}

En el marco del Estado constitucional y democrático de derecho, es comúnmente aceptado que los actos del poder público se hallan gobernados por

6 Díez-Picazo Giménez, Ignacio, "La Constitución y el derecho procesal", Administraciones públicas y Constitución. Reflexiones sobre el XX Aniversario de la Constitución Española de 1978, Madrid, Instituto Nacional de Administración Pública, 1978, p. 265.

7 Desde luego, hay opiniones en sentido diferente. Así, Javier Dondé Matute considera que "en el sistema interamericano, las referencias al PLP (principio de legalidad penal) son, en el mejor de los casos, vagas. Desafortunadamente, la Corte Interamericana de Derechos Humanos no ha tenido oportunidad de desarrollarlo". Principio de legalidad penal: perspectivas del derecho nacional e internacional, México, México UniversitarioBosch, 2007, pp. 362 y 368-369. 
la ley. En ello reside una garantía radical de los individuos frente al Estado. Hay diversas proyecciones de este principio: legalidad general, que abarca todas los actos atribuibles al Estado, y legalidad penal, que se proyecta en la conminación penal - delito y consecuencia-, el enjuiciamiento, las medidas cautelares y la ejecución. ${ }^{8}$ En este apartado nos referiremos brevemente a la legalidad en general; en el siguiente, a sus manifestaciones en materia penal.

Tanto el derecho interno como el internacional recogen el principio de legalidad, que puede verse vulnerado, por lo tanto, en ese doble ámbito. Entre los instrumentos internacionales que se refieren a este asunto figuran: Declaración Universal de los Derechos Humanos (artículo 7o.), Declaración Americana de los Derechos y Deberes del Hombre (artículos V y XXV), Pacto Internacional de Derechos Civiles y Políticos (artículos 6o., 9o. y 14), Convenio Europeo para la Protección de los Derechos Humanos y de las Libertades Fundamentales (artículos 5o., 6o. y 7o.), Carta Africana sobre los Derechos Humanos y de los Pueblos (artículos 6o. y 7.2) y Convención Americana sobre Derechos Humanos (artículo 9o.) cuya interpretación y aplicación competen a la Corte Interamericana.

Otros actos e instrumentos de alcance internacional acogen igualmente el principio que nos ocupa; por ejemplo: Estatuto de la Corte Penal Internacional (artículo 22, nullum crimen sine lege), Código de conducta para funcionarios encargados de hacer cumplir la ley (artículo 1o.) y Resolución 1/08 acerca de Principios y Buenas Prácticas sobre la Protección de las Personas Privadas de Libertad en las Américas, de la Comisión Interamericana de Derechos Humanos. ${ }^{9}$

8 "El principio clásico de legalidad no se aplica sólo al delito. Desde su formulación original se refirió además a la consecuencia de éste, la pena, y luego alcanzó al proceso -órganos persecutorio y judicial, debido proceso-y a la ejecución de la sentencia". García Ramírez, Sergio, La Corte Penal Internacional, 2a. ed., México, Instituto Nacional de Ciencias Penales, 2004, p. 266.

9 Principio IV: "Nadie podrá ser privado de su libertad física, salvo por las causas y en las condiciones establecidas con anterioridad por el derecho interno, toda vez que sean compatibles con las normas del derecho internacional de los derechos humanos (...). Las órdenes y resoluciones judiciales o administrativas susceptibles de afectar, limitar o restringir derechos y garantías de las personas privadas de libertad, deberán ser compatibles con el derecho interno e internacional". 
Se habla de una crisis o un colapso en la concepción tradicional del principio de legalidad; así, Zagrebelsky ${ }^{10}$ y Ferrajoli. ${ }^{11}$ Es innegable que hoy día "no es posible razonar en general partiendo de las premisas del principio de legalidad decimonónico"; 12 éste ha perdido el carácter absoluto que tuvo. El derecho internacional de los derechos humanos - normas y jurisprudencia - introdujo cambios apreciables en esta materia. En algunos sectores se percibe que "la crisis de vinculación de la administración a la ley previa, deriva de la superación, por parte del aparato del Estado, de su función prevalentemente garantizadora y de la asunción de tareas de gestión". ${ }^{13}$ Atienza afirma que la injusticia del mundo es, en buena medida, una injusticia legal, jurídica, producto del contenido de las leyes, resultado de respetar el derecho, no de infringirlo. ${ }^{14}$

Así, es preciso deslindar legalidad de legitimidad; regulación de justificación. Ferrajoli distingue entre legitimación externa e interna. ${ }^{15}$ Pérez Luño observa que sólo la ley legitimada democráticamente constituye un factor de certeza para los ciudadanos. ${ }^{16}$ Convivimos con la vigencia e incluso la aplicación y el cumplimiento de normas legales ilegítimas. ${ }^{17} \mathrm{Se}$ ha observado, con razón, que "la pretensión de legalidad convierte en ilegalidad a toda resistencia y a toda revuelta contra la injusticia y la antijuridicidad (...). Quien domine el 51 por 100 (de los sufragios) podría ilegalizar, de modo legal, al 49 por 100 restante". ${ }^{18}$

${ }^{10}$ Cfr. Zagrebelsky, Gustavo, El derecho dúctil. Ley, derechos y justicia, 7a. ed., trad. Marina Gascón, Madrid, Trotta, 2007, pp. 34-39.

11 Cfr. Ferrajoli, Luigi, Democracia y garantismo, Madrid, Trotta, 2008, p. 258.

12 Zagrebelsky, El derecho dúctil..., cit., p. 36.

13 Ibidem, p. 34.

14 Cfr. Atienza, Manuel, El sentido del derecho, Barcelona, Ariel, 2001, pp. 311 y 312.

15 La primera alude a la "legitimación del derecho penal por referencia a (...) criterios de valoración morales o políticos o de utilidad de tipo extra o meta-jurídico"; la interna implica "la legitimación del derecho penal por referencia a (...) criterios de valoración jurídicos o si se quiere intra-jurídicos". Derecho y razón. Teoría del garantismo penal, 4a. ed., trads. Perfecto Andrés Ibáñez, Alfonso Ruiz Miguel, Juan Carlos Boyón Mohino, Juan Terradillos Basoco y Rocío Cantarero Bandrés, Madrid, Trotta, 2000, p. 213.

16 Pérez Luño, Antonio-Enrique, La seguridad jurídica, Barcelona, Ariel, 1991, pp. 50 y 51 .

${ }^{17}$ Cfr. Bokser, Mirta, Legalidades ilegítimas. Derechos humanos y prácticas sociales, Buenos Aires, Ediciones Colihue, 2002, pp. 30-31.

18 Schmit, Carl, Legalidad y legitimidad, trad. José Díaz García, Madrid, Aguilar, 1971, pp. 46 y 152. 
En consecuencia, conviene que nos preguntemos "de qué modo la legalidad y sus procedimientos formales son capaces de producir legitimidad, es decir, aceptación de las decisiones que resultan de ellos". ${ }^{19}$ ¿Existe una "legalidad ilegítima? ¿qué problemas surgen a partir de este planteamiento? Algunos autores examinan los fundamentos de la legitimidad del derecho: el origen (democrático) y el contenido (justo) de sus normas, cuestiones de difícil valoración cuando prevalecen el relativismo axiológico, la complejidad jurídica y la mala salud democrática. ${ }^{20}$

Cobra importancia la reconsideración de la pura legalidad a la luz del derecho internacional de los derechos humanos, que limita la potestad legislativa de los Estados: en el fondo y en la forma. Es posible arribar a la conclusión de que la protección efectiva y eficaz de los derechos fundamentales del individuo, la preservación de la dignidad humana, el respeto a los valores que se hallan en el fundamento de aquéllos, confieren legitimidad a la ley. En este sentido se pronuncia Atienza cuando afirma que a menudo identificamos la justicia con los derechos humanos o, cuando menos, pensamos que un ordenamiento jurídico que no reconozca o que no sea capaz de proteger eficazmente los derechos fundamentales de los individuos no puede ser calificado como un orden justo. Así, los derechos humanos operan en el contexto de los derechos de los Estados democráticos, como criterios últimos de validez del derecho. ${ }^{21}$

La Corte Interamericana ha sostenido que en un Estado democrático la ley no es simplemente un mandato de la autoridad adoptado conforme a los procedimientos formales regulares. Se exige mucho más: cierto contenido y determinada finalidad. En "una sociedad democrática el principio de legalidad está vinculado inseparablemente al de legitimidad". ${ }^{22}$ Deben coincidir legalidad formal y legalidad (legitimidad) material. ${ }^{23}$

19 Fix-Fierro, Héctor y López Ayllón, Sergio, "Legitimidad y legalidad. Los dilemas de la transición jurídica en el Estado de Derecho en México", Política y gobierno, México, VIII, núm. 2, segundo semestre de 2001, p. 350.

${ }^{20}$ García Manrique, Ricardo, El valor de la seguridad jurídica, México, Fontamara, 2007, p. 17.

${ }^{21}$ Cfr. Atienza, El sentido..., cit., pp. 206 y 213.

22 La expresión "leyes" en el artículo 30 de la Convención Americana sobre Derechos Humanos, Opinión Consultiva OC-6/86, 9 de mayo de 1986, párrafo 32.

23 Cfr. Islas de González Mariscal, Olga, "Principio de legalidad y derechos humanos", Revista Mexicana de Justicia, V, número 4, octubre-diciembre de 1987, México, pp. 129-135. Pérez Luño observa que la legalidad del Estado de Derecho se legitima 


\section{El derecho internacional de los derechos humanos como límite a la discrecionalidad de los Estados}

La soberanía, a la que alguna vez se atribuyó un alcance absoluto, no justifica el menoscabo de los derechos humanos; éstos implican un límite para el ejercicio del poder constituyente (originario o permanente) y de los poderes constituidos. ${ }^{24}$ De ahí que se hable de "la sujeción del Estado constitucional al derecho internacional de los derechos humanos". ${ }^{25}$ Si alguna vez se entendió que los derechos del ser humano sólo adquirían presencia y fuerza en el ámbito de la ley, hoy se advierte que las leyes y la Constitución misma sólo son válidas y democráticas (en el sentido sustancial de la expresión) si reconocen y garantizan los derechos humanos. Aquí se presenta un límite posible y necesario para el desempeño de la autoridad.

Hay expresiones notables del reproche a la ley formalmente válida y materialmente injusta. ${ }^{26}$ Así ocurrió en el famoso caso de los Guardianes del Muro, resuelto por el Tribunal Constitucional Federal de Alemania. ${ }^{27}$ Este decidió que:

formal y materialmente, radicando ésta última en su contenido protector de derechos fundamentales. Pérez Luño, Antonio-Enrique, La seguridad..., cit., p. 50.

24 Así, "los derechos humanos no son producto del ejercicio del poder soberano por parte del Estado sino que actúan como límite frente a éste". Risso Ferrand, Martín, Derecho constitucional, 2a. ed., Fundación de Cultura Universitaria, Montevideo, 2006, pp. 115-118.

25 Expresión de Silva García, Fernando, Derechos Humanos. Efectos de las sentencias internacionales, México, Porrúa, 2007, pp. 72 y 73.

26 Porque "allí donde la injusticia del derecho positivo alcance tales proporciones que la seguridad jurídica garantizada por el Derecho positivo no represente ya nada en comparación con aquel grado de injusticia, no cabe duda de que el derecho positivo deberá ceder el paso a la justicia”. Radbruch, Gustav, Introducción a la filosofía del derecho, trad. de Wenceslao Roces, México, Fondo de Cultura Económica, 1978, p. 44. Radbruch afirma que cuando el derecho positivo "deja a un lado conscientemente la igualdad, que constituye el núcleo de la justicia, entonces no estamos sólo ante una ley que establece un derecho defectuoso, sino que más bien lo que ocurre es que estamos ante un caso de ausencia de Derecho". Radbruch, Gustav, "Leyes que no son derecho y derecho por encima de las leyes", Radbruch, Gustav, Schmidt, Eberhad y Welzel, Hans, Derecho injusto y derecho nulo, Madrid, Aguilar, 1971, pp. 13 y 14.

27 La sentencia del Tribunal Constitucional Federal de Alemania (Bundesverfassungsgericht) en el caso de los Guardianes del Muro -Mauerschützen- (BVerfGE 95, 96) menciona que: "la contradicción de la ley positiva con la justicia debería ser tan insoportable (unerträglich) como para que la ley, en tanto derecho incorrecto (unrichtiges Recht), deba ceder ante la justicia (...). A la luz de todas las consideraciones precedentes, el Tribunal considera que al momento en que fueron cometidos, los actos de los peticionantes 
la justificación de la muerte del fugitivo, resultante del derecho entonces vigente en la RDA, es declarada ineficaz a causa de su agresión abierta e insoportable contra mandatos elementales de la justicia y contra los derechos humanos protegidos por el derecho internacional. En casos semejantes, el derecho ha de ceder ante la justicia. ${ }^{28}$

Así, Alexy ha dado una versión resumida de la fórmula de Radbruch por la cual carece de valor jurídico la norma que pretende amparar una injusticia extrema: "las normas dictadas conforme al ordenamiento y socialmente eficaces pierden su carácter jurídico y su validez jurídica cuando son extremadamente injustas". ${ }^{29}$

La Corte Interamericana entiende que la emisión de una ley contraria a las obligaciones contraídas por los Estados al ratificar la Convención Americana constituye una violación a ésta. El cumplimiento de esa ley por parte de agentes o funcionarios trae consigo responsabilidad internacional para el Estado, independientemente de la responsabilidad criminal en que pudieran incurrir sus ejecutores. ${ }^{30}$

Además, el mismo tribunal asegura que "el derecho internacional impone ciertos límites a la discrecionalidad de los Estados", en particular respecto a las exigencias en la protección de los derechos humanos. ${ }^{31}$

constituían delitos definidos con suficiente cognoscibilidad y previsibilidad por las reglas del derecho internacional en materia de protección de los derechos humanos". Cit. Vigo, Rodolfo (coord.), La injusticia extrema no es derecho. De Radbruch a Alexy, Fontamara, México, 2008, p. 145.

${ }^{28} C f r$. el texto de la sentencia en Alexy, Robert, "Derecho injusto, retroactividad y principio de legalidad penal. La doctrina del Tribunal Constitucional Federal alemán sobre los homicidios cometidos por los centinelas del Muro de Berlín”, Doxa Cuadernos de Filosofía del Derecho, 23, 2000, p. 205.

29 Alexy, "Mauerschützen. Acerca de la relación entre derecho, moral y punibilidad", Vigo, La injusticia ..., cit., p. 269.

${ }^{30}$ Cfr. Responsabilidad Internacional por Expedición y Aplicación de Leyes Violatorias de la Convención (arts. 1 y 2 Convención Americana sobre Derechos Humanos), Opinión Consultiva OC-14/94, 9 de diciembre de 1994, párrafos 50, 54 y 56.

31 Caso Castillo Petruzzi y otros, Sentencia dell 30 de mayo de 1999 (Fondo, Reparaciones y Costas), Serie C, núm. 52, párrafo 101, y Caso Ivcher Bronstein, Sentencia del 6 de febrero de 2001 (Fondo, Reparaciones y Costas), Serie C, núm. 74, párrafo 88. 


\section{EL PRINCIPIO DE LEGALIDAD Y EL SISTEMA INTERAMERICANO de Protección de Derechos Humanos}

\section{Normas de la Convención Americana sobre Derechos Humanos}

El artículo 9o. de la Convención Americana sobre Derechos Humanos establece el "principio de legalidad y de retroactividad" en los siguientes términos:

Nadie puede ser condenado por acciones u omisiones que en el momento de cometerse no fueran delictivos según el derecho aplicable. Tampoco se puede imponer pena más grave que la aplicable en el momento de la comisión del delito. Si con posterioridad a la comisión del delito la ley dispone la imposición de una pena más leve, el delincuente se beneficiará de ello.

Veamos algunos antecedentes de esta disposición en los trabajos de la Conferencia Especializada sobre Derechos Humanos reunida en San José, Costa Rica, en 1969, que aprobó la Convención. El artículo 8 del proyecto de "Convención Interamericana sobre Protección de Derechos Humanos" (que sería artículo 9 de la Convención adoptada) presentado por la Comisión Interamericana de Derechos Humanos ${ }^{32}$ establecía: "Nadie será condenado por actos u omisiones que en el momento de cometerse no fueran delictivos según el derecho aplicable. Tampoco se impondrá pena más grave que la aplicable en el momento de la comisión del delito". ${ }^{33}$ República Dominicana sugirió que ese precepto se identificara como "derecho a no ser sometido a leyes ex post facto". Aunque inicialmente la propuesta fue aceptada, la denominación se modificó en la sesión plenaria del 20 de noviembre de 1969, para quedar como "Principio de legalidad y retroactividad". ${ }^{34}$ Es claro que la legalidad abarca la irretroactividad, es decir, la Convención proscribe la retroactividad de la norma penal desfavorable, como se verá infra, IV, 2 B.

32 Por Resolución del Consejo de la Organización de Estados Americanos (OEA) de 2 de octubre de 1968, dicho proyecto fue enviado a los Estados para la formulación de observaciones y enmiendas previas a la realización de la Conferencia Especializada celebrada en 1969 en Costa Rica.

33 Actas y documentos. Conferencia Especializada Interamericana sobre Derechos Humanos, San José, Costa Rica, 7-22 de noviembre de 1969, Organización de Estados Americanos, p. 17.

34 Ibidem, pp. 59, 206 y 443. 
Las observaciones escritas de Uruguay, Chile, Argentina, República Dominicana, Estados Unidos de América, México, Ecuador, Guatemala y Brasil no aludieron al artículo 8 del proyecto. En la sesión del 13 de noviembre de 1969, el delegado de Ecuador, Juan Isaac Lovato, propuso que se agregase al texto consultado la última parte del artículo 1o. del Pacto Internacional de Derechos Civiles y Políticos de las Naciones Unidas: "Si con posterioridad a la comisión del delito la ley dispone una pena más leve el delincuente se beneficiará de ella". La propuesta fue aprobada.

\section{Control de legalidad en el Sistema Interamericano}

En ejercicio de su función consultiva, la Corte Interamericana ha determinado que "los tratados, convenciones y declaraciones del sistema interamericano en materia de derechos humanos son la fuente principal de obligaciones de los Estados en esta materia y determinan, a su vez, los parámetros de legalidad a los que debe sujetarse la Comisión"35 (Interamericana de Derechos Humanos, cuyas facultades constituían el tema central de la consulta). Así, "en la atención de las peticiones individuales, la Comisión debe respetar los lineamientos establecidos en la Carta de la OEA (artículo 106), la Convención Americana (artículos 41.f, 44 a 51), el Estatuto (artículos 23 y 24) y el Reglamento del propio órgano, que determinan el marco para la legalidad de sus procedimientos". ${ }^{36}$ Es el propio tribunal, "en el ejercicio de sus funciones, (quien) efectúa el control de legalidad de las actuaciones de la Comisión Interamericana de Derechos Humanos en lo que se refiere al trámite de los asuntos que estén bajo el conocimiento de aquélla, conforme a la competencia que le confieren la Convención Americana y otros instrumentos interamericanos de protección de los derechos humanos". ${ }^{37}$

\section{Interpretación y principio de legalidad}

Gregorio Peces-Barba observa que "los derechos aparecen normalmente en las Constituciones, sin que se especifique cuál es su significado

35 Control de Legalidad en el Ejercicio de las Atribuciones de la Comisión Interamericana de Derechos Humanos (arts. 41 y 44 a 51 de la Convención Americana sobre Derechos Humanos), Opinión Consultiva OC-19/05, 28 de noviembre de 2005, párrafo 22.

${ }^{36}$ Ibidem, párrafo 26.

37 Ibidem, opinión 3. 
concreto". ${ }^{38}$ Es preciso, pues, interpretar las normas correspondientes. Esta interpretación, que alcanza las normas nacionales e internacionales sobre derechos humanos, se halla sujeta a reglas específicas.

Con base en el principio de subsidiariedad y complementariedad de la jurisdicción internacional, corresponde a los poderes del Estado en el marco de sus propias atribuciones "velar por el pleno respeto y garantía de todas las obligaciones internacionales asumidas por los distintos países en materia de derechos humanos". ${ }^{39}$ De ahí la necesidad de que conozcan puntualmente el derecho internacional de los derechos humanos. Ahora bien, incumbe a los órganos jurisdiccionales el papel más relevante en materia de interpretación de los derechos humanos: la interpretación jurídica que finalmente prevalecerá corre a cargo de las instancias judiciales, ${ }^{40}$ que cumplen su cometido conforme a diversos métodos o enfoques ${ }^{41}$ y se pliegan al principio pro homine o pro persona,$^{42}$ que rige tanto la interpretación como la creación y aplicación de normas, en general.

Es preciso recordar que los tratados sobre derechos humanos poseen rasgos específicos que los distinguen de otros convenios del orden internacional. Implican la sumisión a un orden legal que trae consigo obligacio-

38 Peces-Barba, Gregorio, Curso de derechos fundamentales. Teoría general, Madrid, Universidad Carlos III, 1995, pp. 577 y 578.

39 Abramovich, Víctor y Courtis, Christian, Los derechos sociales como derechos exigibles, Madrid, Trotta, 2002, p. 72.

40 Rubio Llorente, Francisco, La forma del poder, Madrid, Centro de Estudios Políticos y Constitucionales, 1997, pp. 584-585.

41 Pérez Luño habla de cuatro enfoques o teorías de interpretación de derechos humanos: liberal positivista, del orden de los valores, institucional y jusnaturalista crítica. $C f r$. Derechos humanos, Estado de derecho y Constitución, 9a. ed., Madrid, Tecnos, 2005, pp. 301-316.

42 Definido como el "criterio hermenéutico que informa todo el derecho de los derechos humanos, en virtud del cual se debe acudir a la norma más amplia, o a la interpretación más extensiva, cuando se trata de reconocer derechos protegidos e inversamente, a la norma o interpretación más restringida cuando se trata de establecer restricciones permanentes al ejercicio de los derechos o a su suspensión extraordinaria”. Pinto, Mónica, "El principio pro homine. Criterios de hermenéutica y pautas para la regulación de los derechos humanos", en Abregú, Martín y Courtis, Christian (comps.), La aplicación de los tratados sobre derechos humanos por los tribunales locales, Buenos Aires, Editores del Puerto, 1997, p. 163. Carpio Marcos, siguiendo a Sagués, sostiene que este principio tiene dos variantes: a) Directriz de preferencia interpretativa, que a su vez se compone de: principio favor libertatis y principio de protección a víctimas, y b) Directriz de preferencia de normas. Cfr. Carpio Marcos, Edgar, La interpretación de los derechos fundamentales, Lima, Palestra, 2004, pp. 28-34. 
nes hacia los individuos que se hallan bajo la jurisdicción de los Estados, ${ }^{43}$ no sólo deberes de éstos entre sí. Por otra parte, la Corte Internacional de Justicia, ${ }^{44}$ el Tribunal Europeo de Derechos Humanos (TEDH) ${ }^{45}$ y la Corte Interamericana ${ }^{46}$ han señalado que los tratados de derechos humanos son instrumentos vivos cuya interpretación tiene que acompañar la evolución de los tiempos y las condiciones de vida actuales.

El artículo 29 de la Convención Americana sobre Derechos Humanos contiene diversas normas para la interpretación de ese instrumento (que deben analizarse conjuntamente con las disposiciones provistas por el derecho de los tratados): a) ninguna disposición de la Convención (ni de las Constituciones y las leyes) debe ser interpretada en el sentido de permitir al Estado, a un grupo o a una persona suprimir el goce o ejercicio de los derechos reconocidos en aquélla o limitarlos en mayor medida que la prevista en ella; b) la Convención expresa el "estándar mínimo" para el reconocimiento y la protección de los derechos humanos, es decir, el referente primario del derecho fundamental en el Estado constitucional de derecho, de manera que sus disposiciones tampoco excluyen otros derechos y garantías inherentes al ser humano o derivados de la forma democrática representativa de gobierno; la relación de derechos constituye, en consecuencia, un catálogo abierto; y c) la interpretación debe atenerse al principio de mayor protección de los derechos humanos, que puede localizarse en el derecho interno o en el internacional. ${ }^{47}$

43 Cfr. El efecto de las reservas sobre la entrada en vigencia de la Convención Americana sobre Derechos Humanos, Opinión Consultiva OC-02/82, 24 de septiembre de 1982, párrafos 27-30, y Caso Ivcher Bronstein, Sentencia del 24 de septiembre de 1999 (Competencia), Serie C, núm. 54, párrafos 42-45, donde cita las sentencias del Tribunal Europeo de Derechos Humanos en los casos Irlanda vs Reino Unido y Soering vs. Reino Unido.

${ }^{44}$ Cfr. Legal Consequences for States of the Continued Presence of South Africa in Namibia (South West Africa), notwithstanding Security Council Resolution 276 (1970), Advisory Opinion, 21 June of 1971; pp. 16 y 31 http://www.icj-cij.org/docket/ files/53/5595.pdf.

45 Cfr. Casos Tyrer vs. Reino Unido de 1978, Marckx vs. Bélgica de 1979, Loizidou vs. Turquía de 1995, entre otros.

46 Cfr. Interpretación de la Declaración Americana de los Derechos y Deberes del Hombre en el marco del artículo 64 de la Convención Americana sobre Derechos Humanos, Opinión Consultiva OC-10/89, 14 de junio de 1989, párrafos 37 y 38.

47 Así lo quiso establecer la propuesta de reforma a la Constitución de México en materia de derechos humanos, aprobada por la Cámara de Diputados conforme al Dictamen del 23 de abril de 2009 y publicada en la Gaceta Parlamentaria número 2743-XVI: "Tra- 
La Corte Interamericana ha señalado que la interpretación debe tomar en cuenta el sistema en el que se inscribe el tratado sujeto a examen. ${ }^{48}$ En otro orden, ha precisado que la interpretación que realiza en ejercicio de su competencia consultiva "busca no sólo desentrañar el sentido, propósito y razón de las normas internacionales sobre derechos humanos, sino, sobre todo, asesorar y ayudar a los Estados miembros y a los órganos de la OEA para que cumplan de manera cabal y efectiva sus obligaciones internacionales en la materia" ${ }^{49}$ Los tribunales internos deben asumir, para su desempeño interno, la interpretación adoptada por la Corte Interamericana, habida cuenta de que ésta ha sido instituida por la voluntad soberana de los Estados precisamente con el fin de interpretar y aplicar la Convención. En este sentido, es un órgano de interpretación "oficial" reconocido por los propios Estados. ${ }^{50}$

Es importante reflexionar sobre la posibilidad de que el intérprete se aleje de la "letra de la ley", en procuración de ciertos objetivos. En este orden de consideraciones, se ha manifestado que la interpretación se propone obtener "la operatividad de los derechos ante los constantes cambios sociales de un determinado país". ${ }^{51}$ Esta materia ha sido explora-

tándose de normas de derechos humanos, éstas se interpretarán de conformidad con esta Constitución y en los tratados internacionales de derechos humanos de los que México sea parte. En su aplicación, bajo el principio de no contradicción con esta Constitución, se observarán aquellas que resulten más favorables a los derechos de las personas (artículo 1o., segundo párrafo)". El principio pro persona fue suprimido o matizado por la Cámara de Senadores en su Dictamen del 8 de abril de 2010. La minuta derivada de éste fue remitida a la Cámara de Diputados para efectos del artículo 72, inciso e), constitucional. Esta última Cámara volvió a incorporar el principio pro persona en el Dictamen del 15 de diciembre de 2010 (Gaceta Parlamentaria, número 3162-IV): "Las normas relativas a los derechos humanos se interpretarán de conformidad con esta Constitución y con los tratados internacionales de la materia favoreciendo en todo tiempo a las personas la protección más amplia". El proyecto fue devuelto a la Cámara de Senadores para los efectos del precepto citado. En el ámbito latinoamericano, este principio, junto con el de interpretación conforme a tratados, se encuentra contenido en las Constituciones de Venezuela (artículo 23), Bolivia (artículo 13), Colombia (artículo 93) y Guatemala (artículo 46).

${ }^{4}$ Cfr. Caso Hermanos Gómez Paquiyauri, Sentencia del 8 de julio de 2004 (Fondo, Reparaciones y Costas), Serie C, núm. 110, párrafos 164-165, y Caso Tibi, Sentencia del 7 de septiembre de 2004 (Excepciones preliminares, Fondo, Reparaciones y Costas), Serie C, núm. 114, párrafo 144.

49 Responsabilidad internacional..., cit., párrafo 23.

50 Así lo establece el Estatuto de la Corte Interamericana de Derechos Humanos (artículo 1o.)

51 Carpizo, Enrique, Derechos fundamentales, interpretación constitucional, la Corte y los derechos, México, Porrúa, Instituto Mexicano de Derecho Procesal Consti- 
da por la jurisdicción constitucional, que se ocupa en el examen de la constitucionalidad de la ley secundaria. Al respecto, revisten interés los desenvolvimientos en torno a la llamada "interpretación constitucional conforme" 52 y las "sentencias manipulativas", ${ }^{53}$ entre otros extremos. En ambas hipótesis se pretende conciliar la norma secundaria con la disposición constitucional, evitando una declaración general de inconstitucionalidad. La interpretación debe procurar una efectiva protección de los derechos humanos, atenta a la vertiente "material" de la legalidad. ${ }^{54}$

Como ejemplo de una interpretación que precisa el contenido de una norma, incluso constitucional, en aras de la protección de los derechos de la persona, precisamente a partir de los pronunciamientos de la jurisdicción internacional americana, cabe citar la sentencia del Tribunal Constitucional del Perú ${ }^{55}$ que determina, entre otras cuestiones, el contenido del artículo 173 constitucional con base en los criterios de la Comisión y de la Corte Interamericanas..$^{56}$

tucional, 2009, p. 20.

${ }^{52}$ Fix-Zamudio, Héctor y Ferrer Mac-Gregor, Eduardo, Las sentencias de los tribunales constitucionales, México, UNAM-Porrúa-Instituto Mexicano de Derecho Procesal Constitucional, 2009, pp. 19 y 20.

${ }^{53}$ Eguiguren Praeli, Francisco José, "Las sentencias interpretativas o manipulativas y su utilización por el tribunal constitucional peruano", en Ferrer Mac-Gregor, Eduardo y Zaldívar Lelo de Larrea, Arturo (coords.), La ciencia del Derecho procesal constitucional. Estudios en homenaje a Héctor Fix-Zamudio en sus cincuenta años como investigador del derecho, t. V: juez y sentencia constitucional, México, UNAM, Instituto de Investigaciones Jurídicas, Marcial Pons, Instituto Mexicano de Derecho Procesal Constitucional, 2008, pp. 323-324.

${ }^{54}$ En torno a estas cuestiones y otras aledañas, $c f r$. Ferrajoli, Los retos de la procuración de justicia en un mundo globalizado, México, Ubijus, Instituto de Formación profesional, Procuraduría General de Justicia del Distrito Federal, 2009, p. 28. Un método para la resolución de cierto tipo de antinomias o contradicciones normativas es la ponderación. "Desde luego, no de todas: no de aquellas que puedan resolverse mediante algunos de los criterios al uso, jerárquico, cronológico o de especialidad". Prieto Sanchís, Luis, "Neoconstitucionalismo y ponderación judicial", en Carbonell, Miguel (ed.), Neoconstitucionalismo (s), 3a. ed., Madrid, Trotta-UNAM, 2006, p. 137.

55 Expediente 010-2002-AI/TC- 3 de enero de 2003, acción de inconstitucionalidad contra los decretos leyes $25475,25659,25708$ y 25880 , así como sus normas complementarias y conexas, que puede verse en Diálogo Jurisprudencial, Derecho Internacional de los Derechos Humanos, Tribunales nacionales y Corte Interamericana de Derechos Humanos, Méixo, núm. 1, julio-diciembre 2006, pp. 51-89.

${ }^{56}$ Con base en los criterios de estos órganos internacionales, el Tribunal Constitucional precisa: "si bien el artículo 173 de la Constitución puede ser interpretado en el sentido en que se ha venido efectuando (y que ha cuestionando tanto la Corte como la Comisión 
Por otra parte, atendiendo a la regla de interpretación rigurosa que prevalece en materia penal, se observa que "la interpretación estará permitida si, y sólo si, se mantienen dentro de los límites del sentido del texto de la ley; es decir, la interpretación debe ser acorde con el posible sentido y significado de las palabras. En esa labor serán de gran utilidad los antecedentes históricos de la norma, su función sistemática dentro del orden jurídico y su finalidad. Cuando la interpretación traspasa las fronteras antes señaladas se convierte en analogía prohibida". ${ }^{57}$

\section{FUNCIÓN DEL SISTEMA PENAL}

Antes de ingresar al examen específico del principio de legalidad penal es pertinente considerar ciertos desarrollos de la jurisprudencia interamericana que expresan, desde una perspectiva general, la formación del sistema penal en una sociedad democrática. En este orden, destacan dos cuestiones estrechamente vinculadas entre sí e igualmente asociadas al principio de legalidad, conforme al examen que ha hecho la Corte en diversas sentencias. Nos referimos, sucesivamente, a la idea de derecho penal mínimo y al derecho penal de conducta o hecho en contraste con el derecho penal de autor, que apunta en la inclusión de referencias a la peligrosidad del agente.

\section{Derecho penal mínimo}

Se ha examinado ampliamente, como proyección de ideas políticas y desempeño del poder público, el alcance del sistema penal en una sociedad democrática. En ésta, cumple un papel secundario, como última ratio, control o remedio que se utiliza con moderación, sólo en la medida estrictamente indispensable. Otra cosa ocurre bajo regímenes autoritarios, donde

Interamericana de Derechos Humanos), no es esa la única lectura interpretativa que de dicha cláusula constitucional puede efectuarse (así) el Tribunal Constitucional estima que las disposiciones del Código de Justicia Militar que pueden ser recogidas por la ley, a efectos de ser utilizadas en el procesamiento de civiles acusados de la comisión de delitos de terrorismo y traición a la patria, en ningún caso podrán entenderse como referidas al órgano, sino sólo a las reglas de procedimientos para ser utilizadas por la justicia ordinaria, y siempre que éstas, a su vez, sean acordes con las garantías mínimas del debido proceso previstas en la Constitución".

57 Díaz Aranda, Enrique, Derecho penal. Parte general, México, UNAM-Porrúa, 2003, p. 66. 
se anticipa y extrema el empleo de los instrumentos penales, a través de la tipificación profusa, el enjuiciamiento penal frecuente - en detrimento de otros medios de solución de controversias-, el agravamiento de las sanciones y la ejecución cumplida con la mayor severidad.

En esta dialéctica discurre la idea y la práctica del derecho penal mínimo, acogido en diversas resoluciones de la Corte Interamericana. El tribunal, atento a las mejores corrientes del derecho penal de raíz democrática, entiende que el poder punitivo sólo se despliega en la medida estrictamente necesaria para proteger bienes jurídicos fundamentales contra los ataques más graves que los dañen o pongan en peligro. Lo contrario conduciría al ejercicio abusivo de la potestad punitiva del Estado. ${ }^{58}$ De esta suerte, ha negado la pertinencia de tipificar penalmente comportamientos ilícitos que pudieran ser sancionados por otras vías. Al respecto, destaca la consideración en torno a la responsabilidad exigible al periodista que incurre en exceso cuando ejerce la libertad de expresión. Hasta el presente se ha aceptado, con cierta reticencia, el empleo de la vía penal. ${ }^{59}$

En torno a esta última cuestión, se ha señalado la conveniencia de aplicar la vía civil en esta materia, en virtud de que una sentencia condenatoria de este tipo constituye una declaración de ilicitud no menos enfática y eficaz que la condena penal. La sentencia civil entraña, por sí misma, una reparación consecuente con la necesidad de satisfacer el honor de quien reclama la tutela judicial.

Además puede condenar al pago de ciertas prestaciones correspondientes al daño moral y, en su caso, material, causado a la persona a quien se difamó. Así, "una resolución civil provee las dos especies de reparación

58 Cfr. Caso Kimel, Sentencia del 2 de mayo de 2008 (Fondo, Reparaciones y Costas), Serie C, núm. 177, párrafos 63 y 76.

59 La Corte Interamericana ha señalado que "el derecho penal es el medio más restrictivo y severo para establecer responsabilidades respecto de una conducta ilícita. La tipificación amplia de delitos de calumnia e injurias puede resultar contraria al principio de intervención mínima y de ultima ratio del derecho penal. En una sociedad democrática el poder punitivo sólo se ejerce en la medida estrictamente necesaria para proteger los bienes jurídicos fundamentales de los ataques más graves que los dañen o pongan en peligro". Conforme al "principio de mínima intervención penal característico de una sociedad democrática, el empleo de la vía penal debe corresponder a la necesidad de tutelar bienes jurídicos fundamentales frente a conductas que impliquen graves lesiones a dichos bienes, y guarden relación con la magnitud del daño inferido". Caso Kimel, cit., párrafos 76 y 77; véase también el Voto concurrente razonado del juez Sergio García Ramírez a la sentencia de la Corte en el Caso Kimel, párrafos 14 y 15. 
que revisten mayor interés para el sujeto agraviado, y además entraña, para satisfacción social, el reproche jurídico que merece una conducta ilícita". ${ }^{60}$

\section{Derecho penal de conducta}

Ha llegado al conocimiento de la Corte Interamericana algún caso en que se cuestiona la referencia en el tipo penal a la "peligrosidad" del autor del delito, como dato para el agravamiento de la sanción, que de esta manera puede alcanzar, inclusive, extrema gravedad: pena de muerte. En la atención de este caso, la Corte ha recogido la oposición entre derecho penal de conducta o hecho y derecho penal de autor. ${ }^{61}$

El tribunal internacional determinó que la invocación de peligrosidad plantea el ejercicio del ius puniendi estatal sobre la base de las características personales del agente y no del hecho cometido, es decir, sustituye el derecho penal de hecho o de conducta, propio del sistema democrático, por el derecho penal de autor. Esto constituye una regresión histórica, conduce al autoritarismo punitivo y facilita la persecución de los diferentes, disidentes, discrepantes, marginales, incluso bajo el título de "enemigos". ${ }^{62}$

La valoración de la peligrosidad del imputado implica una apreciación del juzgador acerca de la probabilidad de que aquél incurra en nuevos hechos delictuosos, esto es, agrega a la imputación de los hechos realizados, la previsión de hechos - también en concepto de imputación, si nos atenemos a sus consecuencias - que probablemente ocurrirán en el futuro. El pronóstico será efectuado, en el mejor de los casos, a partir del diagnóstico ofrecido por una pericia psicológica o psiquiátrica del imputado. Sobre esta doble base se despliega la función penal del Estado. En fin de cuentas, se

60 Voto concurrente del juez García Ramírez al Caso Herrera Ulloa, párrafos 14-21. Cfr. Caso Herrera Ulloa, Sentencia del 2 de julio de 2004 (Excepciones Preliminares, Fondo, Reparaciones y Costas), Serie C, núm. 107, párrafos 127-135.

61 Cfr. Caso Fermín Ramírez, Sentencia del 20 de junio de 2005 (Fondo, Reparaciones y Costas), Serie C, núm. 126, párrafos 94-98. Con respecto a esta cuestión, $c f r$. Voto del juez García Ramírez, párrafos 34-38, http://www.corteidh.or.cr/ docs/casos/votos / vsc_garcia_126_esp.doc.

${ }^{62}$ Jakobs afirma que una de las particularidades típicas del Derecho penal del enemigo es el "amplio adelantamiento de la punibilidad, es decir, el cambio de la perspectiva del hecho producido por la del hecho que se va a producir", cfr. La ciencia del derecho penal ante las exigencias del presente, Bogotá, Universidad Externado de Colombia, 2000 , pp. 30 y 31. Para una crítica del derecho penal del enemigo, cfr. Zaffaroni, Eugenio Raúl, El enemigo en el derecho penal, Madrid, Dykinson, 2006, pp. 11-28. 
sancionaría al individuo -inclusive con pena de muerte, como hubiera ocurrido en el Caso Fermín Ramírez - ${ }^{63}$ no con apoyo en lo que ha hecho, sino en lo que es. Sobra ponderar las implicaciones, que son evidentes, de este retorno al pasado, absolutamente inaceptable desde la perspectiva de los derechos humanos.

Por todo lo anterior, la Corte Interamericana sostuvo que consideración de la peligrosidad del agente como criterio para la calificación típica de los hechos y la aplicación de ciertas sanciones, es incompatible con el principio de legalidad criminal y, por ende, contrario a la Convención. ${ }^{64}$

\section{EL PRINCIPIO DE LEGALIDAD EN EL ÁMBITO PENAL}

El principio de legalidad penal ha sido ampliamente examinado por autores clásicos ${ }^{65}$ y contemporáneos. ${ }^{66}$ Aquí sólo nos referiremos a los prin-

63 El artículo 132 del Código Penal de Guatemala estableció: "Comete asesinato quien matare a una persona: 1) Con alevosía; 2) Por precio, recompensa, promesa, ánimo de lucro; 3) Por medio o con ocasión de inundación, incendio, veneno, explosión, desmoronamiento, derrumbe de edificio u otro artificio que pueda ocasionar gran estrago; 4) Con premeditación conocida; 5) Con ensañamiento; 6) Con impulso de perversidad brutal; 7) Para preparar, facilitar, consumar y ocultar otro delito o para asegurar sus resultados o la inmunidad para sí o para sus copartícipes o por no haber obtenido el resultado que se hubiere propuesto al intentar el otro hecho punible; 8) Con fines terroristas o en desarrollo de actividades terroristas. Al reo de asesinato se le impondrá prisión de 25 a 50 años, sin embargo, se le aplicará la pena de muerte en lugar del máximo de prisión, si por las circunstancias del hecho y de la ocasión, la manera de realizarlo y los móviles determinantes, se revelare una mayor particular peligrosidad del agente. A quienes no se les aplique la pena de muerte por este delito, no podrá concedérsele rebaja de pena por ninguna causa".

${ }^{64}$ Cfr. Caso Fermín Ramírez, cit, párrafos 89 y 93-96.

65 Beccaria, Cesar, De los delitos y de las penas, Facsimilar de la edición príncipe en italiano de 1764, seguida de la traducción de Juan Antonio de las Casas de 1774, Fondo de Cultura Económica, México, 2000, pp. 25-73. Cfr. la caracterización de la legalidad penal que hace Roxin, Claus, Derecho penal. Parte general, trad. Diego-Manuel Luzón Peña, Miguel Díaz y García Conlledo y Javier de Vicente Remesal, Madrid, Civitas, 1997, t. I, pp. 134 y ss.

66 Acerca del principio de legalidad, Ferrajoli afirma: "mientras que el axioma de mera legalidad se limita a exigir la ley como condición necesaria de la pena y del delito (nulla poena, nullum crimen sine lege), el principio de estricta legalidad exige todas las demás garantías como condiciones necesarias de la legalidad penal (nullum lex poenalis sine necessitate, sine iniuria, sine actione, sine culpa, sine iudicio, sine accusatione, sine probatione, sine defensione)", Derecho y razón..., cit., pp. 93-95. Cfr. asimismo, entre 
cipales aspectos de dicho principio, en los términos de la jurisprudencia interamericana. La CorteIDH cuenta con una abundante jurisprudencia en esta materia. Ha establecido que en un Estado de derecho "los principios de legalidad e irretroactividad presiden la actuación de todos los órganos del Estado", pero adquieren especial importancia cuando se ejerce el poder punitivo de éste sobre los gobernados ${ }^{67}$ Bajo la misma razón — ejercicio del poder punitivo - , la Corte Interamericana también ha establecido la observancia del principio de legalidad en otros ámbitos en los que se previene la existencia de faltas y la aplicación de sanciones; así, el administrativo. ${ }^{68}$

\section{Ley escrita}

\section{A. Concepto de "ley"}

Al amparo del artículo 30 de la Convención Americana - restricciones a los derechos - la legalidad comprende dos dimensiones: formal y material. Aquella existe cuando se ha observado el procedimiento establecido para la creación de leyes o su reforma; la material atiende al contenido de la norma: respetuoso de los derechos humanos, en el marco de la sociedad democrática.

Para que una norma merezca el título de ley en los términos del citado artículo 30, es preciso: a) que se trate de una "norma jurídica de carácter

otros, Cárdenas Rioseco, Raúl F., El principio de legalidad penal, México, Porrúa, 2009; Arroyo Zapatero, Luis, "Principio de legalidad y reserva de ley en materia penal", Revista Española de Derecho Constitucional, Madrid, año 3, número 8, mayo-agosto 1983, p. 10; Ruiz Robledo, Agustín, El derecho fundamental a la legalidad punitiva, Valencia, Tirant lo Blanch, 2003, pp. 111 y 205, y Huerta Tocildo, Susana, "El derecho fundamental a la legalidad penal", Revista Española de Derecho Constitucional, Madrid, año 13, número 39, septiembre- diciembre 1993, p. 108.

${ }^{67}$ Caso Baena Ricardo y otros, Sentencia del 2 de febrero de 2001 (Fondo, Reparaciones y Costas), Serie C, núm. 72, párrafo 107; Caso Ricardo Canese, Sentencia del 31 de agosto de 2004 (Fondo, Reparaciones y Costas), Serie C, núm. 111, párrafo 177; Caso De la Cruz Flores, Sentencia del 18 de noviembre de 2004 (Fondo, Reparaciones y Costas), Serie C, núm. 115, párrafo 80; Caso Lori Berenson Mejía, Sentencia del 24 de noviembre de 2004 (Fondo, Reparaciones y Costas), Serie C, núm. 119, párrafo 126; Caso Fermín Ramírez, cit., párrafo 90; Caso García Asto y Ramírez Rojas, Sentencia del 25 de noviembre de 2005 (Excepción Preliminar, Fondo, Reparaciones y Costas), Serie C, núm. 137, párrafos 187, y Caso Vélez Loor, Sentencia del 23 de noviembre de 2010 (Excepciones Preliminares, Fondo, Reparaciones y Costas), Serie C, núm. 218, párrafo 183.

68 Cfr. Caso Baena Ricardo y otros, cit., párrafos 124-129. 
general, ceñida al bien común, emanada de los órganos legislativos constitucionalmente previstos y democráticamente elegidos, y elaborada según el procedimiento establecido por las Constituciones de los Estados partes para la formación de las leyes" ${ }^{69}$, y b) que la norma responda a razones de interés general y sirva al propósito para el que fue establecida. En la especie, razones de interés general significa que la norma corresponda a los requerimientos del bien común. ${ }^{70}$ Estos conceptos, que han sido aplicados en opiniones consultivas ${ }^{71}$ y en la solución de litigios ${ }^{72}$ ante la misma Corte, deben ser recogidos por los Estados al momento de crear, interpretar o aplicar leyes.

\section{B. Tipos penales y consecuencias de la formulación imprecisa}

Como regla general, observemos que "las leyes están dirigidas a todos los ciudadanos, (y por ello) deben estar formuladas en términos que permitan a cualquier ciudadano la comprensión del sentido de prohibición”. La identificación de la conducta ilícita y de su consecuencia penal "se materializa (en) el principio de legalidad, limitando el uso arbitrario del poder punitivo del Estado". ${ }^{73}$

El tema es complejo y ha sido examinado por la doctrina y por tribunales nacionales e internacionales. El principio de estricta legalidad o taxatividad penal implica que los términos empleados por la ley para describir los comportamientos punibles tengan una extensión cierta, evitando expresiones vagas y valorativas. ${ }^{74}$ Carnevali Rodríguez observa los problemas que genera el principio de legalidad en la Unión Europea por el uso cada vez más frecuente de términos imprecisos y ambiguos bajo el argumento de "adaptación a necesidades político-criminales cambiantes además de que una taxatividad absoluta imposibilitaría la resolución de conflictos sociales". ${ }^{75}$

69 La expresión "leyes" en el artículo 30..., cit., párrafos 26-30 y 35.

70 Cfr. Idem.

71 A manera de ejemplo: Exigibilidad del Derecho de Rectificación o Respuesta (arts. 14.1, 1.1 y 2 Convención Americana sobre Derechos Humanos), Opinión Consultiva OC7/86, 29 de agosto de 1986, párrafo 31.

72 Por ejemplo: Caso Baena Ricardo y otros..., cit, párrafos 169 y 170.

73 Díaz-Aranda, Derecho penal..., cit., p. 62.

74 Ferrajoli, Derecho y razón..., cit., p. 121.

75 Carnevali Rodríguez, Raúl, Derecho penal y derecho sancionador de la Unión Europea, Granada, Comares, 2001, pp. 187-192. 
De Vicente Martínez afirma que "un recorrido por la jurisprudencia del Tribunal Europeo de Derechos Humanos, al tratar el principio de tipicidad o taxatividad de la ley penal, nos lleva a la conclusión de que en todas las sentencias el TEDH ha acabado desestimando la violación del principio de tipicidad". ${ }^{76}$ Evidentemente, la "falibilidad del legislador abre la posibilidad de que las normas soporten diversas interpretaciones". ${ }^{77}$ Por su parte, el Tribunal Constitucional Español ha sostenido en reiteradas ocasiones "que no vulnera la exigencia de lex certa, como garantía de la certidumbre o seguridad jurídica, el empleo (de) normas sancionadoras (que contengan) conceptos jurídicos indeterminados, siempre que su concreción sea razonablemente factible en virtud de criterios lógicos, técnicos o de experiencia que permitan prever, con suficiente seguridad, la conducta regulada". ${ }^{78}$

El artículo 9o. de la Convención Americana obliga a los Estados a definir las acciones u omisiones delictivas en forma clara y precisa. ${ }^{79}$ Lo contrario implica violación de ese precepto ${ }^{80}$ Conforme a la jurisprudencia interamericana, que se ha ocupado en caracterizar la legalidad formal y material como antes señalamos, es necesario que la formulación de tipos penales sea clara, precisa, de manera que expresen sin equívoco la conducta incriminada, deslindándola de otros comportamientos ${ }^{81}$ Es debido utilizar conceptos de

76 De Vicente Martínez, Rosario, El principio de legalidad penal, Valencia, Tirant lo Blanch, 2004, p. 192.

77 Orsi, Omar Gabriel, Los límites del legislador penal. Discurso penal y programa constitucional, Buenos Aires, Editores del Puerto, 2007, p. 41.

78 Sentencia STC 150/1991 (publicada en BOE el 7 de julio de 1991), que a su vez cita las sentencias SSTC 122/1987, 133/1987, 69/1989 y 219/1989. Previamente, la sentencia STC 71/1982 (publicada en el BOE el 29 de diciembre de 1982) sostuvo: "La seguridad jurídica enlaza con el principio de reserva de Ley, y en sentido más general con el de legalidad, y también requiere certeza en la regla de Derecho y proscribe fórmulas proclives a la arbitrariedad. No ha de considerarse vulnerada, sin embargo, cuando la Ley utiliza conceptos indeterminados indispensables por cuanto no son sustituibles por referencias concretas, y se remite a reglamentaciones especificas y complementarias en áreas en que la complejidad técnica, la prontitud de actuación y las precisiones normativas así lo exigen".

79 Cfr. Caso Fermín Ramírez, cit, párrafo 90 y Caso Castillo Petruzzi y otros, cit., párrafo 121 .

${ }^{80}$ Cfr. Caso Baena Ricardo y otros, cit., párrafo 108.

81 Cfr. Caso Castillo Petruzzi y otros, cit., párrafos 119 y 121; Caso García Asto y Ramírez Rojas, cit, párrafos 188 y 195; Caso Lori Berenson Mejía, cit, párrafo 125; Caso Cantoral Benavides, Sentencia del 18 de agosto de 2000 (Fondo), Serie C, núm. 69, párrafo 157; Caso Fermín Ramírez, cit., párrafo 90; Caso De la Cruz Flores, cit, párrafo 
alcance determinado en relación con las conductas típicas, los elementos con que se realizan, los objetos o bienes contra los que se dirigen y el efecto que tienen sobre el grupo social. ${ }^{82}$ De otra suerte, se descaracterizan los tipos penales ${ }^{83}$ y pueden asimilarse entre sí, con graves consecuencias en contra de la persona y sus derechos. ${ }^{84}$

El uso de términos ambiguos, la existencia de elementos comunes en varias conductas incriminadas y la imprecisión en el deslinde de tipos penales repercuten en la sanción aplicable, el tribunal de conocimiento y el proceso correspondiente, que puede pasar de ordinario a sumario, con mayor o menor reducción de garantías. ${ }^{85}$ Así, se abre el campo al arbitrio de la autoridad ${ }^{86}$ particularmente lesivo o peligroso en esta materia. Además, la deficiente o incompleta definición del hecho punible alienta la inadmisible integración analógica. ${ }^{87}$ En suma, es indispensable utilizar términos estrictos y unívocos en la formulación de tipos penales, que acoten claramente las conductas punibles.

\section{Ley previa}

\section{A. Seguridad jurídica y ley previa}

El artículo 9 de la Convención Americana dispone que "nadie puede ser condenado por acciones u omisiones que en el momento de cometerse

79, y Caso Usón Ramírez, Sentencia del 20 de noviembre de 2009 (Excepción Preliminar, Fondo, Reparaciones y Costas), Serie C, núm. 207, párrafo 55. Respecto a la ley a lex certa, praevia, scripta y stricta, cfr. Roxin, Derecho penal..., cit., t. I, pp. 140 y 141; asimismo, Malo Camacho, Gustavo, Derecho penal mexicano, México, Porrúa, 1997, pp. 106-109.

82 Cfr. Caso Cantoral Benavides, cit, párrafo 155.

83 Cfr. Ibidem, párrafo 156, y Caso Castillo Petruzzi y otros, cit, párrafo 119.

84 Cfr. Caso Lori Berenson Mejía, cit, párrafo 117; Caso Cantoral Benavides, cit, párrafo 156, y Caso Castillo Petruzzi y otros, cit, párrafo 119.

85 Cfr. Caso Castillo Petruzzi y otros, cit, párrafo 119; Caso Cantoral Benavides, cit, párrafo 156; Caso Lori Berenson Mejía, párrafo 119.

${ }^{86}$ Cfr. Caso Castillo Petruzzi y otros, cit, párrafo 121; Caso Lori Berenson Mejía, cit, párrafo 125; Caso Cantoral Benavides, cit, párrafo 157.

87 García Ramírez, La Corte Penal..., cit., p. 47. Como es sabido, la analogía supone aplicación de "la norma penal a un caso no previsto en ella, con el argumento de su semejanza con otros supuestos sí previstos en la ley como delitos". Díaz Aranda, Derecho penal..., cit, p. 67. 
no fueran delictivos según el derecho aplicable". A este respecto, la Corte sostiene que en aras de la seguridad jurídica es indispensable que la norma punitiva exista y resulte conocida, o pueda serlo, antes de que ocurran la acción o la omisión que la contravienen y que se pretende sancionar. ${ }^{88}$

Esta cuestión - al igual que otros extremos del principio de legalidadsuscita consideraciones interesantes bajo el common law, un orden jurídico construido a base de casos y costumbre. Viene a cuentas un "derecho tradicionalmente constituido por las decisiones de las cortes. El jurista necesita referirse a los principios manejados en las resoluciones de justicia y de ellos obtiene la regla conforme a la cual no sólo se ha manejado el derecho sino que podrá resolverse en el futuro". ${ }^{89} \mathrm{Al}$ amparo del stare decisis, "los casos (que se presenten en el futuro) se decidirán bajo el mismo método (con el que lo fueron) en el pasado". ${ }^{90}$ Así, el principio de legalidad experimenta un giro muy importante en el derecho anglosajón que prevé "la vinculación del juez, tanto al precedente judicial —el common law-, como al derecho legal emanado del Parlamento — statute law-, constituyendo así un sistema jurídico penal con características propias". ${ }^{91}$

\section{B. Irretroactividad de la ley penal desfavorable}

La sanción penal se halla sujeta a las normas imperantes en el momento en que los hechos punibles ocurrieron. El Estado no aplicará retroactivamente las leyes que establezcan o agraven - por medio de nuevos elementos de la descripción normativa - tipos penales o punibilidades. Ninguna persona puede ser sancionada por un hecho que no era delictuoso, sancionable o perseguible al tiempo en que fue realizado..$^{92}$ El princi-

${ }^{8}$ Cfr. Caso Baena Ricardo y otros, cit, párrafo 106; Caso De la Cruz Flores, cit, párrafo 104; Caso García Asto y Ramírez Rojas, cit, párrafo 206.

${ }^{89}$ López Monroy, José de Jesús, Sistema jurídico de common law, México, Porrúa, 1999, p. 125.

90 Ibidem, p. 165.

91 García Ramírez, La Corte Penal Internacional, cit., p. 235.

92 Cfr. Caso Baena Ricardo y otros, cit, párrafo 106; Caso Ricardo Canese, cit, párrafo 175; Caso De La Cruz Flores, cit, párrafo 105, y, Caso García Asto y Ramírez Rojas, cit, párrafo 191. En el sistema europeo de protección de derechos humanos, cfr. el Caso Jamil vs. Francia, del 8 de junio de 1995; el tribunal "expone con más firmeza el reconocimiento del principio de no retroactividad penal”, Vicente Martínez de, El principio de legalidad..., cit., pp. 197 y 198. 
pio de irretroactividad de la ley penal desfavorable suscita cuestiones que ameritan cuidadoso examen. ${ }^{93}$

El artículo 15 del Pacto Internacional de Derechos Civiles y Políticos dispone: a) nadie será condenado por actos u omisiones que no eran delictuosos en el momento de su realización, según el derecho nacional o internacional; b) tampoco se impondrá pena más grave que la aplicable cuando se cometió el delito; c) si con posterioridad a la comisión del ilícito penal la ley dispone la aplicación de una pena más leve, el delincuente se beneficiará de esta circunstancia. El mismo precepto prescribe, en otro fragmento, que la exclusión señalada $s u b$ a) no impide, sin embargo, que se sancionen las acciones $u$ omisiones que eran atípicas conforme a la ley escrita, pero resultaban punibles de acuerdo con los principios generales del derecho reconocidos por la comunidad internacional. ${ }^{94}$

Esta salvedad — que pudiera no serlo, bajo determinado criterio- se ha presentado en algunos casos, como el mencionado, supra I, 3, de los Guardianes del Muro. En sus términos, es sancionable la conducta que contraviene aquellos principios generales, aun cuando se halle permitida o justificada por la ley nacional. ${ }^{95} \mathrm{~A}$ este régimen se atuvo el Tribunal Constitucional Federal alemán. En el mismo sentido se orientan la Convención sobre la Imprescriptibilidad de los Crímenes de Guerra y de los

93 Cfr. Burgoa, Ignacio, Las garantías individuales, 40a. ed., México, Porrúa, 505-525; Fix-Zamudio, Héctor, "Comentario al artículo 14 constitucional", Constitución Política de los Estados Unidos Mexicanos comentada, México, UNAM, 1985, pp. 36-39, y Carbonell, Miguel, Los derechos fundamentales en México, México, UNAM, 2004, pp. 636-652.

${ }^{9}$ Cfr. Klug, Ulrich, Problemas de la filosofía y de la pragmática del derecho, México, Fontamara, 1992, pp. 177 y 178. Esta misma salvedad se encuentra establecida en el Convenio Europeo para la Protección de los Derechos Humanos y de las Libertades Fundamentales (artículo 7o.).

95 En este sentido cfr. Pérez Luño, La seguridad..., cit., pp. 93 y 94, y Klug, ibidem, pp. $178-180$. 
Crímenes de Lesa Humanidad ${ }^{96}$ y el Estatuto de Roma de la Corte Penal Internacional..$^{97}$

En la misma línea de preocupaciones figura la posibilidad de aplicar la ley penal internacional cuando ésta incrimina hechos que no están previstos, a título de delitos, por la normativa penal interna. Esta posibilidad se deduciría del amplio alcance que pudiera darse a la expresión del artículo $9 \mathrm{CADH}$ sobre el derecho aplicable: tanto nacional como internacional, tomando en cuenta para los fines de esta interpretación algún antecedente en la formación de aquél precepto. ${ }^{98}$

\section{Retroactividad de la ley penal favorable}

La prohibición de retroactividad protege al individuo frente a la aplicación arbitraria y sorpresiva del ius puniendi; impide la restricción de los derechos fundamentales por medio de la conminación penal y la persis-

96 La Convención fue adoptada el 26 de noviembre de 1968. El artículo I señala que se prevendrá y sancionará el delito de genocidio "aun si esos actos no constituyen una violación del derecho interno del país donde fueron cometidos". México firmó la Convención el 3 de julio de 1969 y la ratificó el 15 de marzo de 2002, al hacerlo formuló la siguiente declaración interpretativa: "Con fundamento en el artículo 14 de la Constitución Política de los Estados Unidos Mexicanos, el Gobierno de México, al ratificar la Convención sobre la Imprescriptibilidad de los Crímenes de Guerra y de los Crímenes de Lesa Humanidad, adoptada por la Asamblea General de las Naciones Unidas el 26 de noviembre de 1968, entenderá que únicamente considerará imprescriptibles los crímenes que consagra la Convención, cometidos con posterioridad a su entrada en vigor para México".

97 Cfr. artículos 22, 23 y 33. México firmó el Estatuto de Roma el 7 de septiembre de 2000 pero ratificó dicho instrumento internacional hasta el 28 de octubre de 2005 . Aunque el Estatuto de Roma no admite reservas (artículo 120), el Estado mexicano realizó una "reserva encubierta" al reformar el artículo 21 constitucional en 2005. Cfr. Becerra Ramírez, Manuel, "México ratifica el Estatuto de Roma que crea la Corte Penal Internacional, después de reformar la Constitución”, Anuario..., cit., pp. 151 y ss.

98 Medina Quiroga menciona una propuesta del gobierno de Colombia: que se aluda explícitamente al derecho nacional e internacional, en lugar de emplear el término "derecho aplicable". El presidente de la Comisión explicó que la referencia no era necesaria, puesto que la expresión "derecho aplicable" comprendía tanto el derecho nacional como el internacional. Cfr. Conferencia Especializada ..., op. cit., p. 206. Medina Quiroga se refiere a "la posibilidad de que pueda castigarse un delito no tipificado en el derecho nacional, si éste existe como crimen de derecho internacional, haciendo uso de la jurisdicción universal”. Medina Quiroga, Cecilia, La Convención Americana: teoría y jurisprudencia, San José, Universidad de Chile, Facultad de Derecho, 2005, p. 347. 
tencia de sanciones cuya gravedad ha sido cuantitativa o cualitativamente atenuada. ${ }^{99}$ En contraste con el régimen de irretroactividad desfavorable, es ampliamente reconocido el principio de aplicación de la ley penal favorable emitida después de la realización de la conducta ilícita o la imposición de la sanción por parte de los tribunales.

La retroactividad de la ley más favorable está prevista, entre otros instrumentos, en el Pacto Internacional de Derechos Civiles y Políticos (artículo 15.1, ya mencionado) y en el artículo 9 de la Convención Americana sobre Derechos Humanos. Sobre esta materia, la Corte Interamericana señala que una ley es favorable cuando: a) elimina un tipo penal; b) reduce - cuantitativa o cualitativamente - la sanción anteriormente prevista; c) crea una nueva causa de justificación o de inculpabilidad; o d) excluye o extingue la persecución penal de ciertos hechos. ${ }^{100} \mathrm{La}$ Corte Interamericana considera aplicable el principio de retroactividad de la ley penal más favorable con respecto a leyes sancionadas antes de la emisión de la sentencia o durante su ejecución, ya que la Convención no establece una restricción en ese sentido. ${ }^{101}$

El relevo de normas corresponde a nuevos conceptos sobre justificación o eficacia de la punición en supuestos específicos. Carecería de sentido mantener el rigor penal cuando la evolución de las ideas o de las circunstancias impone moderación punitiva. ${ }^{102}$

En torno a la retroactividad favorable se plantean diversas cuestiones, que los tratadistas analizan. Una de ellas concierne al cambio de naturaleza de la pena, no sólo de intensidad, y viene al caso decidir cuál es la pena mayor. ${ }^{103}$ Otra, corresponde a la aplicación de la retroactividad una vez que la sentencia condenatoria adquiere fuerza ejecutoria. ${ }^{104}$ También es pertinente observar que en ocasiones la norma posterior es favorable sólo en algunos aspectos; esto llevaría a la aplicación de los términos más favorables de ambas normas, en función del principio pro reo o pro homine. ${ }^{105}$

99 Huerta Tocildo, "El derecho fundamental a la legalidad..., cit., p. 97.

${ }^{100}$ Cfr. Caso Ricardo Canese, cit, párrafo 179.

${ }^{101}$ Idem.

${ }^{102}$ Cfr. Cuerda Riezu, "La aplicación..., cit., pp. 275-290.

${ }^{103}$ Cfr. Medina Quiroga, La Convención..., cit., p. 351.

${ }^{104}$ Idem.

${ }^{105}$ Cuerda Riezu observa que estas formulaciones sólo se refieren a un supuesto de sucesión de leyes, pero no mencionan el cambio de naturaleza del ilícito, que pasa a constituir una infracción de menor entidad. Sostiene que "es lógico que el principio de 


\section{Irretroactividad y competencia de la Corte Interamericana}

El panorama de la irretroactividad adquiere complejidades apreciables cuando se trata de violaciones que se prolongan en el tiempo, como ocurre en la hipótesis que el derecho penal conoce bajo el rubro de "delitos continuos o permanentes"; la misma calificación — sin incorporar la calificación delictuosa, propia del derecho punitivo - se aplica a las violaciones continuas: aquellas en que la conducta contraventora no se agota en un momento, sino persiste indefinidamente.

Este problema se plantea en los supuestos de desaparición forzada, muy frecuentes en la experiencia americana llevada al conocimiento del tribunal internacional de derechos humanos. Se actualiza tanto en la caracterización de la violación como en la apreciación sobre los derechos vulnerados y la competencia de la Corte para conocer de los hechos que se someten a su jurisdicción. ${ }^{106}$ En el Caso Ticona Estrada se examinó este último punto, tomando en cuenta la fecha en que el Estado reconoció la competencia contenciosa de la Corte. Conforme a su jurisprudencia constante, el tribunal declaró que

puede ejercer su competencia ratione temporis para examinar, sin infringir el principio de irretroactividad, aquellos hechos que constituyen violaciones de carácter continuo o permanente, es decir, aquellos que tuvieron lugar antes

retroactividad in bonam partem comprenda también estos dos supuestos". Cuerda Riezu, "La aplicación retroactiva de las leyes favorables y el principio de legalidad penal en clave constitucional", en Balado Ruiz-Gallego, Manuel et. al. (coords.), La declaración universal de los derechos humanos en su 50 aniversario, Barcelona, Bosch, 1998, p. 283. En concepto de Ruiz Robledo, la retroactividad in bonus es aplicable únicamente a las disposiciones sancionadoras y a las restrictivas de derechos, no a cualquiera más beneficiosa para los actores. Cfr. Ruiz Robledo, El derecho fundamental..., cit., pp. 111 y 201.

${ }^{106}$ Algunos Estados han formulado explícita limitación al conocimiento, por parte de la Corte Interamericana, de violaciones continuas; así, Chile: "los reconocimientos de competencia que ha conferido se refieren a hechos posteriores a la fecha del depósito de este instrumento de ratificación o, en todo caso, a hechos cuyo principio de ejecución sea posterior al 11 de marzo de 1990", y El Salvador: "los casos en que se reconoce la competencia, comprende(n) sola y exclusivamente hechos o actos jurídicos posteriores o hechos o actos jurídicos cuyo principio de ejecución sean posteriores a la fecha del depósito de esta Declaración de Aceptación". Véase http://www. oas.org/Juridico/spanish/firmas/b-32.html. 
de la fecha de reconocimiento de la competencia de la Corte y persisten aún después de esa fecha. ${ }^{107}$

Sin perjuicio de aceptar unánimemente el carácter continuo de la violación cometida, así como el deber de investigarla, algunos jueces consideraron que la Corte debe ser especialmente rigurosa en la apreciación sobre el reconocimiento de la competencia contenciosa por parte de un Estado. La Corte no puede aceptar el conocimiento de una causa si no consta, de manera suficiente, la oportuna admisión de su competencia por parte del Estado al que se dirige la demanda. ${ }^{108}$ El tribunal sostuvo que cuando un Estado reconoce hechos ocurridos antes de la admisión de competencia, debe entenderse que "ha renunciado a cualquier limitación temporal al ejercicio de la competencia de la Corte, y por tanto, ha reconocido la competencia contenciosa para que ésta examine todos los hechos ocurridos y se pronuncie sobre las violaciones que se configuren en (el) caso". ${ }^{109}$

\section{Legislador y tipificación}

\section{A. Conductas legítimas}

Nos hemos referido al límite que establece el derecho internacional de los derechos humanos con respecto a la potestad normativa del Estado nacional.

${ }^{107}$ Cfr. Caso Heliodoro Portugal, Sentencia del 12 de agosto de 2008 (Excepciones Preliminares, Fondo, Reparaciones y Costas), Serie C, núm. 186, párrafo 25, y Caso Ticona Estrada y otros, Sentencia del 27 de noviembre de 2008 (Fondo, Reparaciones y Costas), Serie C, núm. 191, párrafos 29 y 30.

${ }^{108} \mathrm{La}$ "Corte no puede asumir por decisión propia una competencia que no se le ha conferido. Se trata de un punto de derecho que debe recibir una respuesta jurídica, con absoluta independencia de cualesquiera opiniones particulares sobre la conveniencia o inconveniencia de asumir la competencia sobre hechos ajenos a ella, en un acto de "autoridad judicial" que carecería de fundamento normativo y que podría resultar, por eso mismo, arbitrario. La Corte no puede sustituir con un acto de voluntad propia - que desborda las fronteras de la interpretación admisible - al acto de voluntad del Estado en materias que corresponden a las decisiones de éste, no a las atribuciones de aquélla (...) La Corte no puede suponer la existencia del reconocimiento, infiriéndola de expresiones aisladas, ambiguas o equívocas, a las que el Estado no atribuya claramente la naturaleza y la eficacia de un reconocimiento". Voto razonado conjunto de los Jueces Diego GarcíaSayán y Sergio García Ramírez en el Caso Ticona Estrada, cit., http://www.corteidh. or.cr/casos.cfm.

${ }^{109}$ Cfr. Caso Ticona Estrada, cit., párrafos 29 y 30. 
Este asunto se planteó a la Corte Interamericana a propósito de la punición del "acto médico". En la especie, el tribunal entendió que se violenta el principio de legalidad cuando se penaliza un acto de esa naturaleza (lícito por sí mismo y, además, obligatorio para los profesionales de la medicina) y se impone a los médicos la obligación de denunciar posibles conductas delictivas de sus pacientes con base en la información que obtengan en el ejercicio de su profesión. La Corte sostuvo que los profesionales de la medicina tienen el derecho y el deber de guardar confidencialidad sobre la información a la que tengan acceso en su condición de médicos que brindan el servicio de su profesión. ${ }^{110}$

Es inadmisible sancionar penalmente la conducta del médico que presta atención destinada a proteger la salud y preservar la vida de otras personas, con independencia de las características de éstas, sus actividades y convicciones y el origen de sus lesiones o enfermedades. Por otra parte, es necesario excluir de incriminación la conducta del médico que se abstiene de informar a las autoridades la conducta punible en que ha incurrido su paciente, de la que se halla al tanto por la confidencia que éste le hace con motivo del acto médico. En este caso podría operar una excusa absolutoria similar a la que ampara a los familiares del imputado en casos de encubrimiento por favorecimiento. ${ }^{111}$

De las consideraciones expresadas por la Corte se desprende nuevamente que el legislador interno no puede sancionar conductas legítimas. Para establecer la identidad y características de éstas es pertinente recurrir a la normativa internacional, que en el caso de los profesionales de la medicina es abundante y creciente, y cubre diversos ámbitos del cuidado de la salud. ${ }^{112}$

\section{B. Obligación de adoptar medidas legislativas}

Los Estados deben adoptar medidas - legislativas, entre ellas - para tutelar bienes jurídicos protegidos por la Convención y convertir la juridicidad convencional en legalidad interna. Con ello se atiende, además, al respeto

${ }^{110}$ Cfr. Caso De La Cruz Flores, cit, párrafos 97, 101-102.

111 Cfr. Caso De La Cruz Flores, cit, voto razonado del juez García Ramírez, párrafo 13, en García Ramírez, Sergio, Temas de la jurisprudencia interamericana sobre derechos humanos. Votos particulares, México, ITESO/ Universidad Iberoamericana, p. 332.

112 Cfr. García Ramírez, La responsabilidad penal del médico, 2a. ed., Porrúa, UNAM, México, 2006, pp. 54-63. 
y la garantía de los derechos humanos reconocidos en aquel instrumento. La adopción de medidas está prevista en el artículo 2o. de la $\mathrm{CADH}$. La adecuación del orden interno al internacional implica medidas en dos vertientes: a) expedición de normas y desarrollo de prácticas conducentes a la efectiva observancia de dichas garantías, y b) supresión de normas y prácticas de cualquier naturaleza que entrañen violación a las garantías previstas en la Convención o que desconozcan o perturben el ejercicio de los derechos que aquélla reconoce.

En relación con la obligación general de adecuar la normativa interna a la Convención, la Corte ha reiterado que "una norma consuetudinaria (del derecho de gentes) prescribe que un Estado que ha celebrado un convenio internacional, debe introducir en su derecho interno las modificaciones necesarias para asegurar la ejecución de las obligaciones asumidas". ${ }^{113}$ Desde las primeras sentencias —así, en el Caso Velásquez Rodríguez- la Corte Interamericana ha insistido en la obligación constante, continua y permanente de adecuar (la) legislación interna a la Convención. ${ }^{114}$ Por otra parte, "el Estado está obligado a desarrollar en su legislación aquellos derechos que en su formulación internacional carecen de la precisión necesaria para que puedan ser aplicados por los órganos del Estado y, especialmente, para que puedan ser invocados ante los tribunales de justicia". ${ }^{115}$

Esta obligación no atenta — como alguna vez se alegó - contra la soberanía de los Estados, a los que incumbe la potestad legislativa en el ámbito de su jurisdicción. En ejercicio de aquélla los Estados asumen el deber de respetar y garantizar los derechos enunciados por las convenciones de la materia, establecen los órganos y las jurisdicciones de supervisión y aceptan sujetarse a los pronunciamientos que la justicia internacional adopta en el desempeño de la encomienda de interpretación y aplicación que los propios Estados le han atribuido.

Si los Estados tienen, de acuerdo con el artículo 2o. de la Convención Americana, la obligación positiva de adoptar las medidas legislativas necesarias para el respeto y la garantía de los derechos reconocidos por la $\mathrm{CADH}$, con mayor razón están obligados a abstenerse de expedir leyes que

${ }^{113}$ Caso Garrido y Baigorria, Sentencia del 27 de agosto de 1998 (Reparaciones y Costas), Serie C, núm. 39, párrafo 68.

${ }^{114}$ En este sentido se ha pronunciado la Corte en múltiples ocasiones, entre ellas, Caso Castillo Petruzzi y otros, cit, párrafo 207.

${ }^{115}$ Medina Quiroga, La Convención ..., cit., p. 25. 
desconozcan esos derechos o perturben su ejercicio, así como a suprimir o modificar las que tengan este alcance. ${ }^{116}$ La sola existencia de una ley que contraviene los derechos humanos, puede ser, per se, violatoria de la Convención, aunque todavía no se haya realizado ningún acto de ejecución. ${ }^{117}$

\section{Obligación de tipificar ciertas conductas}

La Corte Interamericana destaca la obligación de los Estados, derivada de tratados internacionales, de acoger en su derecho interno las fórmulas penales (tipos y punibilidades) necesarias para la persecución de conductas violatorias de derechos humanos; así, tortura y desaparición forzada. Con respecto a esta última, afirmó que la ausencia de tipo adecuado a propósito de la desaparición, como delito autónomo, obstaculiza el desarrollo efectivo del proceso penal y fomenta la impunidad. La obligación de tipificar estos hechos surge a partir del momento en que entra en vigor la Convención Interamericana sobre Desaparición Forzada de Personas para el Estado respectivo. ${ }^{118}$

En lo que concierne a la tortura, la Corte ha precisado que el Estado que ha contraído el compromiso internacional de sancionarla debe incorporar en su legislación los tipos penales que permitan llevar a cabo la persecución penal correspondiente, conforme a los instrumentos internacionales, sin restar elementos o introducir limitaciones que desvirtúen la punición dispuesta por aquéllos. ${ }^{119}$

En este sentido, el derecho internacional establece los elementos mínimos que debe considerar la correcta tipificación de algunas conductas delictivas; el Estado debe tomar en cuenta esos elementos. La sustracción de los que tienen carácter irreductible según la fórmula persecutoria internacional, así como la introducción de modalidades que le resten sentido o eficacia, determina la impunidad de conductas que los Estados están obligados a prevenir, erradicar y sancionar, de acuerdo con el derecho internacional.

${ }^{116}$ Cfr. Caso Hilaire, Constantine y Benjamín y otros, Sentencia del 21 de junio de 2002 (Fondo, Reparaciones y Costas), Serie C, núm. 94, párrafos 113 y 116.

${ }^{117}$ Responsabilidad internacional..., Opinión Consultiva 14/94, cit, párrafo 43.

${ }^{118}$ Cfr. Caso Heliodoro Portugal, cit., párrafos 107, 179-191 y Caso Goiburú y otros, Sentencia del 22 de septiembre de 2006 (Fondo, Reparaciones y Costas), Serie C, núm. 153, párrafos 83 y 84 .

${ }^{119}$ Cfr. Caso Goiburú y otros, cit., párrafos 91 y 93. 
Las descripciones imprecisas o incompletas del supuesto de hecho contravienen las exigencias del principio de legalidad y de seguridad jurídica. ${ }^{120}$ Una tipificación inadecuada puede conducir a los mismos resultados que la ausencia de tipificación.

\section{Graduación de gravedad (categorías de tipos y penas)}

La Corte Interamericana ha examinado el problema que se presenta cuando la legislación interna — aplicada por los órganos jurisdiccionales y traducida en actos de ejecución y condena - sanciona de manera uniforme e indiscriminada diversos supuestos delictivos que afectan principalmente un mismo bien jurídico, pero no revisten idéntica gravedad atendiendo a los diversos elementos o circunstancias que concurren en ellos. La regulación nacional suele distinguir, a estos fines, entre tipos básicos y calificados. En la consideración de este asunto, el tribunal tuvo a la vista hipótesis de privación de la vida (homicidio) a las que la normativa interna aplicaba pena capital, recogida como mandatory death penalty. ${ }^{121}$

La Corte apreció que los supuestos de homicidio intencional ${ }^{122}$ deben figurar bajo distintas categorías (tipos penales) que correspondan a la diversa gravedad de los hechos, tomando en cuenta los elementos que pueden concurrir en ellos: especiales relaciones entre el delincuente y la víctima, móvil de la conducta, circunstancias en las que ésta se realiza, medios empleados por el sujeto activo, etcétera. De esta forma se establecerá una graduación en la gravedad de los hechos, a la que corresponderá una graduación en la severidad de la pena aplicable. ${ }^{123}$

${ }^{120}$ Cfr. Caso Heliodoro Portugal, cit, párrafos 189-191, 208, 215 y 216, y voto razonado del juez García Ramírez, http://www.corteidh.or.cr/docs/casos/votos/vsc_garcia_186_esp.doc.

${ }^{\overline{1} 21}$ Cfrr. García Ramírez, "La pena de muerte en la Convención Americana sobre Derechos Humanos y en la jurisprudencia de la Corte Interamericana", Boletín Mexicano de Derecho Comparado, México, año XXXVIII, núm. 114, septiembre-diciembre 2005, pp. 1053 y ss.

${ }^{122}$ La Corte Interamericana ha señalado que la lucha de los Estados contra el delito de homicidio debe desarrollarse con pleno respeto a los derechos humanos de las personas sometidas a su jurisdicción y de conformidad con los tratados aplicables. Caso Durand y Ugarte, Sentencia del 16 de agosto de 2000 (Fondo), Serie C, núm. 68, párrafo 69, y Caso Bámaca Velásquez, Sentencia del 25 de noviembre de 2000 (Fondo), Serie C, núm. 70, párrafos 172 y 174.

${ }^{123}$ Cfr. Caso Hilaire, Constantine y Benjamin y otros, cit, párrafo 102. 
Esta cuestión fue materia de examen en un caso notable que suponía la imposición obligatoria de pena de muerte, sin considerar los elementos particulares que concurrían en la especie. ${ }^{124} \mathrm{Si}$ una ley ordena la aplicación de la pena de muerte de manera automática y genérica para cualquier supuesto de homicidio intencional, el juez de la causa no podrá considerar datos básicos para determinar el grado de culpabilidad del agente e individualizar la pena. En este caso el juzgador se ve obligado a considerar la categoría del delito, sin tomar en cuenta las condiciones personales del justiciable ni las circunstancias particulares del delito y, por tanto, impone mecánicamente la pena prevista en forma genérica para cualquier sujeto responsable de homicidio intencional. Además el supuesto establecía la imposibilidad de que la sanción impuesta se modificara por parte de un órgano judicial superior. ${ }^{125}$ Todo esto contraviene el artículo 4.1 CADH e implica arbitrariedad, particularmente grave cuando se encuentra en riesgo el bien jurídico mayor, la vida humana.

\section{Verificación de la conducta y aplicación de la ley. Control de convencionalidad}

En el curso del enjuiciamiento es preciso extremar las precauciones para que las medidas penales se adopten con estricto respeto a los derechos básicos de las personas y previa verificación cuidadosa de la efectiva existencia de la conducta ilícita que se atribuye al inculpado. ${ }^{126} \mathrm{El} \mathrm{juez} \mathrm{que}$ aplica la ley penal debe atenerse estrictamente a lo dispuesto por ésta y apreciar la rigurosa adecuación de la conducta del inculpado al tipo penal; el descuido del juzgador conduce a la penalización judicial de actos que no son punibles legalmente. ${ }^{127}$ El rigor en la observancia de las garantías del inculpado debe extremarse cuando existe la posibilidad de aplicar pena de muerte. ${ }^{128}$

${ }^{124}$ Voto concurrente del juez García Ramírez, Caso Hilaire, Constantine y Benjamin y otros, cit, http://www.corteidh.or. cr/docs/casos/votos/vsc_garcia_94_esp.doc.

${ }^{125}$ Cfr. Caso Hilaire, Constantine y Benjamin y otros, cit, párrafos 101-107.

${ }^{126}$ Cfr. Caso Baena Ricardo y otros, cit, párrafo 106; Caso De la Cruz Flores, cit, párrafo 81; Caso Fermín Ramírez, cit, párrafo 90, y Caso García Asto y Ramírez Rojas, cit, párrafo 189.

${ }^{127}$ Cfr. Caso De la Cruz Flores, cit, párrafo 82; Caso Fermín Ramírez, cit, párrafo 90; Caso García Asto y Ramírez Rojas, cit., párrafo 190.

${ }^{128}$ Véanse notas 160,161 y 162. 
Podemos mencionar aquí - así sea en forma sumaria, por las conexiones que tiene con el deber judicial de aplicar las normas pertinentes a los casos sub judice-, un tema cada vez más destacado: el control de convencionalidad. ${ }^{129}$ Este se relaciona estrechamente con la recepción nacional del derecho internacional de los derechos humanos. ${ }^{130}$ Uno de los autores de este artículo analizó el control de convencionalidad a cargo de los jueces nacionales, ${ }^{131}$ es decir, la aplicación directa, por parte de éstos, de las normas del derecho internacional de los derechos humanos en los asuntos sujetos a su jurisdicción. Los jueces nacionales tendrían la obligación de ejercer el control de convencionalidad. ${ }^{132}$ Obviamente, esta aplicación directa serviría muy significativamente a la inserción nacional del derecho internacional y, con ello, a la protección más amplia de los derechos fundamentales. En 2006, este concepto fue retomado por la jurisprudencia de la Corte en la

${ }^{129}$ En interesante estudio reciente, María Carmelina Londoño Lázaro ha examinado la convergencia entre el principio de legalidad y el control de convencionalidad. Cfr. "El principio de legalidad y el control de convencionalidad de las leyes: confluencias y perspectivas en el pensamiento de la Corte Interamericana de Derechos Humanos", Boletín Mexicano de Derecho Comparado, número 128, mayo-agosto 2010, pp. 761-814.

${ }^{130}$ Un estudio más amplio de este tema se puede encontrar en: García Ramírez, Sergio, y Morales Sánchez, Julieta, "La jurisprudencia de la Corte Interamericana de Derechos Humanos en el periodo 2007-2009", Anuario Iberoamericano de Justicia Constitucional, Madrid, 13, 2009, pp. 497-539.

${ }^{131}$ García Ramírez afirmó que "para los efectos de la Convención Americana y del ejercicio de la jurisdicción contenciosa de la Corte Interamericana, el Estado viene a cuentas en forma integral, como un todo"; de ahí que todos los órganos del Estado deban atenerse a los criterios sustentados por el tribunal internacional a propósito de la Convención; bajo ésta, interpretada por su propia instancia judicial, se realiza el control externo de convencionalidad. Cfr. Voto concurrente razonado del juez Sergio García Ramírez a la sentencia de la Corte en el Caso Myrna Mack Chang del 25 de noviembre de 2003, párrafo 27, http://www.corteidh.or.cr/casos.cfm. Posteriormente el mismo juez observó que "en la lógica del sistema - y en las aspiraciones institucionales de la Corte Interamericana, como elemento de éste- reside la idea de que los pronunciamientos del tribunal deben trasladarse, en la forma y términos que provea el derecho interno - que son el puente entre el sistema internacional y el nacional-, a las leyes nacionales, a los criterios jurisdiccionales domésticos, a los programas específicos en este campo y a las acciones cotidianas que el Estado despliega en materia de derechos humanos; trasladarse, en fin, al conjunto de la experiencia nacional". Voto concurrente razonado del juez Sergio García Ramírez a la sentencia de la Corte en el Caso Tibi, cit., párrafos 3-6, idem.

${ }^{132}$ A este respecto, véase el voto razonado del juez ad hoc Eduardo Ferrer Mac-Gregor Poisot a la sentencia de la Corte Interamericana de Derechos Humanos en el Caso Cabrera García y Montiel Flores del 26 de noviembre de 2010. 
sentencia del Caso Almonacid Arellano y otros. ${ }^{133}$ Algunos tratadistas se han referido a esta aportación a la jurisprudencia interamericana. ${ }^{134}$

Por otra parte, al examinar la posición de los jueces como garantes del respeto a los derechos humanos, Ferrajoli observa que la sujeción del juez a la ley ya no es apenas sumisión a la letra de la norma, sino sujeción a la ley en la medida en que ésta es válida, es decir, coherente con la Constitución. El juzgador, garante de los derechos fundamentales constitucionalmente establecidos, encuentra aquí el principal fundamento de la legitimidad de su jurisdicción ${ }^{135}$. En este punto reiteramos la referencia a la legalidad formal y la legalidad —o legitimidad — material, así como a la conformidad de la ley con los principios y las disposiciones del derecho internacional de los derechos humanos. Existiría, pues, una doble coherencia: con la Constitución, que promueve el control de constitucionalidad, y con la norma internacional, que suscita el control de convencionalidad.

A propósito de la aplicación de la ley, se plantea también la elección de la norma aplicable al caso, no sólo en razón de su fecha (tema de retroactividad) o en virtud de su estricta adecuación a los hechos (tema de tipicidad), sino también del contenido de aquélla, más o menos benéfico o benévolo, y en este sentido favorable para el inculpado. Como antes dijimos, la Corte

${ }^{133}$ Cuando "un Estado ha ratificado un tratado internacional como la Convención Americana, sus jueces, como parte del aparato del Estado, también están sometidos a ella, lo que les obliga a velar porque los efectos de las disposiciones de la Convención no se vean mermadas por la aplicación de leyes contrarias a su objeto y fin, y que desde un inicio carecen de efectos jurídicos. En otras palabras, el Poder Judicial debe ejercer una especie de 'control de convencionalidad' entre las normas jurídicas internas que aplican en los casos concretos y la Convención Americana sobre Derechos Humanos. En esta tarea, el Poder Judicial debe tener en cuenta no solamente el tratado, sino también la interpretación que del mismo ha hecho la Corte Interamericana, intérprete última de la Convención Americana". Caso Almonacid Arellano y otros, Sentencia del 26 de septiembre de 2006 (Excepciones Preliminares, Fondo, Reparaciones y Costas), Serie C, núm. 154, párrafo 124.

${ }^{134}$ Cfr. Rey Cantor, Ernesto, Control de convencionalidad de las leyes y derechos humanos, Porrúa, Instituto Mexicano de Derecho Procesal Constitucional, México, 2008, pp. 46 y 167-171; Hitters, Juan Carlos, Control de constitucionalidad y control de convencionalidad. Comparación, en La Ley (Buenos Aires), 27 de julio de 2009, pp. 1-5, y García Morelos, Gumesindo, Control Judicial Difuso de Convencionalidad de los Derechos Humanos por los Tribunales Ordinarios en México, México, Ubijus, 2010.

${ }^{135}$ Cfr. Ferrajoli, Luigi, Derechos y garantías. La ley del más débil, trad. Perfecto Andrés Ibáñez y Andrea Greppi, 4a. ed., Madrid, Trotta, 2004, p. 26. 
Interamericana ha recogido el principio de la norma más favorable; ${ }^{136}$ si son aplicables dos disposiciones distintas a una misma situación, "debe prevalecer la norma más favorable a la persona humana". ${ }^{137}$ Conforme al artículo 29. b) $\mathrm{CADH}$, si alguna ley del Estado Parte u otro tratado internacional del cual sea Parte dicho Estado otorga una mayor protección o regula con mayor amplitud el goce y ejercicio de algún derecho o libertad, éste deberá aplicar la norma más favorable para la tutela de los derechos humanos. ${ }^{138}$

\section{Límites al ejercicio del poder público}

El ejercicio del poder público, como injerencia del Estado en el ámbito de derechos y libertades individuales, se halla sujeto a la ley. Otros principios acotan, asimismo, ese desempeño, pero en todo caso impera la regla de legalidad en la que se sustentan —o debieran sustentarse - cualesquiera expresiones de autoridad y fuerza del Estado en aquel ámbito. En este apartado nos referiremos a algunos actos del poder público que frecuentemente llegan al conocimiento de la jurisdicción interamericana y acerca de los cuales hay jurisprudencia relevante y en ocasiones reiterada.

\section{A. Uso de la fuerza}

Los Estados tienen la obligación de crear y garantizar las condiciones necesarias para que no se produzcan violaciones de derechos humanos en el ámbito de su jurisdicción. Esta obligación considera tanto la violación proveniente de agentes del poder público como el ataque en que incurran

${ }^{136}$ Cfr. Ciertas atribuciones de la Comisión Interamericana de Derechos Humanos (arts. 41, 42, 44, 46, 47, 50 y 51 de la Convención Americana sobre Derechos Humanos), Opinión Consultiva OC-13/93 del 16 de julio de 1993, Serie A, núm. 13, párrafo 54; Caso Baena Ricardo y otros, Sentencia del 18 de noviembre de 1999 (Excepciones Preliminares), Serie C, núm. 61, párrafo 37; Caso Baena Ricardo y otros (Fondo) cit., párrafo 189, y Caso Herrera Ulloa, cit., párrafo 184.

${ }^{137}$ En una clara aplicación del principio pro persona. Cfr. La Colegiación Obligatoria de Periodistas (artículos 13 y 29 Convención Americana sobre Derechos Humanos), Opinión Consultiva OC-5/85 del 13 de noviembre de 1985, Serie A, núm. 5, párrafo 52, y Caso Ricardo Canese, cit, párrafo 180. Como antes se dijo, en el proceso de reforma a la Constitución Política de los Estados Unidos Mexicanos, a propósito de derechos humanos, hubo diversas fórmulas sobre esta materia. Véase nota 48.

${ }^{138}$ Caso Ricardo Canese, cit, párrafo 180. 
los particulares. ${ }^{139}$ Implica que el despliegue de las acciones del Estado esté sujeto a límites precisos. ${ }^{140}$

La Corte ha señalado que está más allá de toda duda que el Estado tiene el derecho y el deber de garantizar su propia seguridad, utilizando la fuerza si es necesario, pero cualquier acción debe ejercerse dentro de los límites y conforme a los procedimientos que permiten preservar tanto la seguridad pública como los derechos humanos. Tampoco se ignora que la sociedad padece por las infracciones a su orden jurídico. Sin embargo, por graves que sean ciertas acciones y por culpables que resulten los reos de determinados delitos, no es admisible que el poder se ejerza sin límite alguno o que el Estado pueda valerse de cualquier procedimiento para alcanzar sus objetivos, sin sujeción al derecho o a la moral. Ninguna actividad del Estado puede fundarse sobre el desprecio a la dignidad humana. El respeto a los derechos humanos constituye un límite infranqueable; la administración no puede invocar el orden público para reducir discrecionalmente las garantías de los gobernados. Prevalece, pues, la regla de racionalidad en el ejercicio de la función pública. En este sentido se ha mencionado que el dogma que sostiene que "el fin justifica los medios" debiera sustituirse por un principio de signo contrario: "la legitimidad de los medios empleados justifica y acredita el fin alcanzado". ${ }^{141}$ La función primordial del Estado es salvaguardar los derechos humanos en todas las circunstancias. ${ }^{142}$

${ }^{139}$ Cfr. Caso Baldeón García, Sentencia del 6 de Abril de 2006 (Fondo, Reparaciones y Costas), Serie C, núm. 147, párrafo 83; Caso de las Masacres de Ituango, Sentencia del 1 de julio de 2006, Serie C, núm. 148, párrafo 129; Caso Montero Aranguren y otros (Retén de Catia), Sentencia del 5 de julio de 2006, Serie C, núm. 150, párrafo 64; Caso del Penal Miguel Castro Castro, Sentencia del 25 de noviembre de 2006 (Fondo, Reparaciones y Costas), Serie C, núm. 160, párrafo 237.

${ }^{140}$ Cfr. Caso Durand y Ugarte, cit., párrafo 69; Caso Bámaca Velásquez, cit., párrafos 143 y 174, y Caso Juan Humberto Sánchez, Sentencia del 7 de junio de 2003 (Excepción Preliminar, Fondo, Reparaciones y Costas) Serie C, núm. 99, párrafo 111.

${ }^{141}$ Cfr. García Ramírez, Panorama del proceso penal, México, Porrúa, 2004, pp. 35 y 64.

${ }^{142}$ Cfr. Caso Velásquez Rodríguez, Sentencia del 29 de julio de 1988 (Fondo), Serie C, núm. 4, párrafo 154; Caso Godínez Cruz, Sentencia del 20 de enero de 1989 (Fondo), Serie C, núm. 5, párrafo 162; Caso Neira Alegría y otros, Sentencia del 19 de enero de 1995 (Fondo), Serie C, núm. 20, párrafo 75; Caso Castillo Petruzzi y otros, cit, párrafos 89 y 204; Caso Durand y Ugarte, cit., párrafos 68 y 69; Caso Bámaca Velásquez, cit., párrafos 143 y 174; Caso Baena Ricardo y otros, cit., párrafo 126; Caso del Caracazo, Sentencia del 29 de agosto de 2002 (Reparaciones y Costas), Serie C, núm. 95, párrafo 127; Caso Juan Humberto Sánchez, cit., párrafos 86 y 111; Caso Bulacio, Sentencia del 
Ahora bien, los Estados responden por las acciones y las omisiones de sus agentes, realizados al amparo de su desempeño oficial, como también cuando actúan fuera de los límites de su competencia o contravienen el derecho interno. Deben velar, especialmente, por el respeto al derecho a la vida por parte de los cuerpos de seguridad pública, a los que se atribuye el uso de la fuerza legítima. ${ }^{143}$ Los Estados tienen que adoptar las medidas necesarias para prevenir y castigar la privación de la vida como consecuencia de actos criminales, así como para prevenir y sancionar ejecuciones arbitrarias cometidas por miembros de sus propias fuerzas de seguridad; ${ }^{144}$ esta situación se agrava cuando existe un patrón de violaciones de los derechos humanos. ${ }^{145}$

Hay estándares internacionales sobre el uso de la fuerza por parte de los agentes del Estado, frecuentemente invocados por la Corte Interamericana. ${ }^{146} \mathrm{El}$ uso de la fuerza, adecuadamente planeado, es admisible para la obtención de fines legítimos; se sujeta a principios de proporcionalidad y excepcionalidad; procede cuando se han utilizado y agotado, sin éxito, otros medios de control. La ley debe regular con criterio restrictivo el empleo de fuerza letal y armas de fuego: en la medida "absolutamente necesaria" con respecto a la fuerza o amenaza que se pretende repeler. De no ser así, el empleo de la fuerza devendrá arbitrario. Esto es aplicable, inclusive, cuando surgen condiciones de inseguridad en establecimientos penitenciarios, que

18 de septiembre de 2003, Serie C, núm. 100, párrafo 124; Caso Lori Berenson Mejía, cit., párrafo 91, y Caso Montero Aranguren y otros (Retén de Catia), cit., párrafo 70.

${ }^{143}$ Cfr. Caso Bámaca Velásquez, cit., párrafo 172; Caso Juan Humberto Sánchez, cit, párrafo 111; Caso Myrna Mack Chang, Sentencia del 25 de noviembre de 2003 (Fondo, Reparaciones y Costas), Serie C, núm. 101, párrafo 139; Caso Hermanos Gómez Paquiyauri, cit., párrafo 128; Caso de la “Masacre de Mapiripán”, Sentencia del 15 de septiembre de 2005 (Fondo, Reparaciones y Costas) Serie C, núm. 134, párrafo 232; Caso Baldeón García, cit., párrafo 87; Caso Montero Aranguren y otros (Retén de Catia), cit., párrafos 65 y 66; Caso Servellón García, Sentencia del 21 de septiembre de 2006 (Fondo, Reparaciones y Costas) Serie C, núm. 152, párrafo 102, y Caso del Penal Miguel Castro Castro, cit., párrafo 238.

${ }^{144}$ Cfr. Caso de la "Masacre de Mapiripán”, cit., párrafo 232, y Caso Baldeón García, cit., párrafo 87;

${ }^{145}$ Cfr. Caso Myrna Mack Chang, cit., párrafo 139; Caso Hermanos Gómez Paquiyauri, cit., párrafo 128, y Caso Baldeón García, cit., párrafo 87.

${ }^{146}$ Que se encuentran, entre otros, en el Código de Conducta para Funcionarios Encargados de Hacer Cumplir la Ley y en los Principios Básicos sobre el Empleo de la Fuerza y de Armas de Fuego. 
el Estado tiene obligación de prevenir. ${ }^{147}$ Es necesario optar, ante todo, por medidas de prevención.

La Corte Interamericana destaca la importancia de formar y capacitar a los miembros de los cuerpos armados y de seguridad para el debido ejercicio de sus atribuciones, dotándoles de entrenamiento adecuado. Es necesario limitar rigurosamente la actuación de las fuerzas armadas en el control de disturbios internos; el entrenamiento que éstas reciben se concentra en la derrota del enemigo, no en la protección y el control de civiles, como es propio de los entes policiales. Los cuerpos armados y los organismos de seguridad deben contar con la preparación necesaria para aplicar medios respetuosos de los derechos humanos al enfrentar alteraciones del orden público. Los planes operativos deben incluir medidas de control de la actuación de los miembros de los cuerpos de seguridad en el terreno mismo de los hechos, para evitar excesos. ${ }^{148}$ Es preciso adoptar procedimientos que permitan verificar la legalidad del uso de fuerza letal por agentes estatales; cuando se emplee esta fuerza el Estado debe llevar adelante la investigación correspondiente — seria, imparcial y efectiva—, de oficio y sin dilación, ${ }^{149}$ abierta al escrutinio público. Aquélla comprenderá todas las circunstancias del caso y su contexto, inclusive las acciones de planeación y control de los hechos sujetos a examen. ${ }^{150}$

También ha precisado la Corte Interamericana que el uso desproporcionado de la fuerza por parte de miembros del ejército para controlar un motín dentro de un centro de reclusión, no debe ser considerado delito militar; su investigación y sanción corresponden a la jurisdicción ordinaria, independientemente de la condición, militar o civil, de los supuestos autores ${ }^{151}$.

${ }^{147}$ Cfr. Caso Neira Alegría y otros, cit, párrafos 74-76, y Caso Montero Aranguren y otros (Retén de Catia), cit., párrafos 67-71.

${ }^{148}$ Cfr. Caso del Caracazo, cit., párrafo 127.

${ }^{149}$ Cfr. Caso del Caracazo, cit., párrafos 118-120; Caso de la "Masacre de Mapiripán", cit., párrafo 219; Caso de la Masacre de Pueblo Bello, Sentencia del 31 de enero de 2006 (Fondo, Reparaciones y Costas), Serie C, núm. 140, párrafo 143; Caso Baldeón García, cit., párrafo 92, y Caso Montero Aranguren y otros (Retén de Catia), cit., párrafo 79.

${ }^{150}$ Cfr. Caso Montero Aranguren y otros (Retén de Catia), cit., párrafo 82.

${ }^{151}$ Cfr. Caso Durand y Ugarte, cit., párrafos 118, 119 y 125. La Corte también ha dicho que en un Estado democrático de Derecho, la jurisdicción penal militar debe tener alcance restrictivo y excepcional, limitado a las contiendas que versen sobre bienes jurídicos inherentes a la función castrense y a las personas que se hallan en servicio activo en las fuerzas armadas. De no ser así, se vulnera el derecho al juez natural, presupuesto del debido proceso. Cfr. Caso Castillo Petruzzi, cit., párrafo 128; Caso Cantoral Benavides, 
Procede mencionar que la jurisprudencia interamericana ha sido clara, enfática y constante en la acotación rigurosa del ámbito objetivo y subjetivo de la jurisdicción militar, tema relevante en la expresión jurisprudencial del derecho interamericano de los derechos humanos. Sólo es admisible el ejercicio de la jurisdicción castrense con respecto a militares en ejercicio y en lo que concierne a ilícitos estrictamente vinculados a la función militar ${ }^{152}$.

\section{B. Reacción frente a delitos graves}

Ya señalamos que el Estado tiene el deber de proteger a la sociedad y garantizar su propia seguridad y el orden público, pero en este cometido debe actuar dentro de los límites que impone, en una sociedad democrática, el respeto a los derechos humanos. Este concepto aparece en la Convención Interamericana que vincula a los Estados de la región en el combate al terrorismo ${ }^{153}$. Las disposiciones - letra y orientación general- de ese instrumento constituyen un buen punto de referencia para la actuación del Estado en la prevención y persecución de delitos graves, que suele replantear ante la opinión pública un falso dilema: derechos humanos o seguridad pública; debido proceso o control de la delincuencia. ${ }^{154}$

Por supuesto, la escrupulosa tutela de los derechos fundamentales no conduce, en modo alguno, a justificar o tolerar la violencia terrorista -

cit., párrafo 75; Caso Almonacid Arellano y otros, cit., párrafo 131; Caso La Cantuta, Sentencia del 29 de noviembre de 2006 (Fondo, Reparaciones y Costas) Serie C, núm. 162, párrafos 135-145, y Caso Escué Zapata, Sentencia del 4 de Julio de 2007 (Fondo, Reparaciones y Costas), Serie C, núm. 165, párrafo 105.

${ }^{152}$ Cfr. Caso Radilla Pacheco, cit., párrafos 273-275.

${ }^{153}$ En el ámbito americano, se cuenta con la Convención Interamericana contra el Terrorismo, suscrita el 3 de junio de 2002, durante el Trigésimosegundo Periodo Ordinario de Sesiones de la Asamblea de la Organización de los Estados Americanos. Interesa mencionar que la propia Asamblea adoptó también, en esta misma sesión, la resolución sobre "Derechos humanos y terrorismo" que México prohijó. Se resolvió "reafirmar que la lucha contra el terrorismo debe realizarse con pleno respeto a la ley, a los derechos humanos y a las instituciones democráticas para preservar el Estado de Derecho, las libertades y los valores democráticos en el Hemisferio". Cfr. García Ramírez, Sergio, "Consideraciones sobre terrorismo" en Olloqui, José Juan de (coord.), Problemas jurídicos y políticos del terrorismo, UNAM, Instituto de Investigaciones Jurídicas, México, 2003, pp. 67-123.

${ }^{154}$ Cfr. García Ramírez, La reforma penal constitucional de 2007-2008. ¿Democracia o autoritarismo?, 4a. ed., México, Porrúa, 2010, pp. 4 y ss. 
cualesquiera que sean sus protagonistas - ni otras expresiones de la criminalidad más lesiva o peligrosa que se vale de métodos extraordinariamente violentos. Esta delincuencia lesiona a los individuos y al conjunto de la sociedad y merece el más enérgico rechazo. Así lo ha manifestado la Corte, enfáticamente, en diversos pronunciamientos. ${ }^{155}$

\section{Pena de muerte}

Existe una importante normativa internacional acerca de la pena de muerte. Diversos instrumentos se refieren a esta cuestión, que reviste la mayor trascendencia en la tutela de los derechos fundamentales del ser humano - la vida misma - y en el progreso de las ideas y las prácticas penales. Aunque gradualmente crece el número de los Estados abolicionistas - de jure y de facto - frente al de los Estados retencionistas, el derecho internacional ha dispuesto restricciones estrictas para la imposición o ejecución de la pena de muerte. ${ }^{156}$ En este sentido, las Salvaguardias para garantizar la protección de los derechos de los condenados a la pena de muerte de Naciones Unidas, ${ }^{157}$ representan un instrumento importante en el establecimiento de obligaciones que los Estados deben cumplir. ${ }^{158}$

${ }^{155}$ Entre ellos, cfr. Caso Castillo Petruzzi y otros, cit., párrafo 89.

${ }^{156}$ Tanto el artículo 6 del Pacto Internacional de Derechos Civiles y Políticos como el artículo 4 de la Convención Americana sobre Derechos Humanos, restringen y condicionan la previsión y aplicación de la pena de muerte. En 1989 se adoptó el Segundo Protocolo facultativo del Pacto Internacional de Derechos Civiles y Políticos, destinado a abolir la pena de muerte. En 1990 se aprobó el Protocolo a la Convención Americana sobre Derechos Humanos relativo a la abolición de la pena de muerte. El artículo 2 del Convenio Europeo para la Protección de los Derechos Humanos y de las Libertades Fundamentales se refiere, con orientación reductora, a la pena capital. En 1983 se adoptó el Protocolo núm. 6 al Convenio Europeo, y en 2002 el Protocolo núm. 13, que avanzan en la dirección abolicionista. Cfr. Morales Sánchez, Julieta, "Derecho Internacional de los Derechos Humanos y pena de muerte", en Oliveira de Barros Leal, César (coord.), Serie de Estudios en Ciencias Penales y Derechos Humanos. Homenaje a Antonio Sánchez Galindo, Guanajuato, Instituto Estatal de Ciencias Penales, Instituto Brasileño de Derechos Humanos, Congreso del Estado de Guanajuato, 2010, t. I, pp. 329-355.

${ }^{157}$ Aprobadas por el Consejo Económico y Social en su resolución 1984/50, del 25 de mayo de 1984.

${ }^{158}$ Entre las que se encuentran: A) La pena de muerte sólo podrá imponerse como sanción para los delitos más graves, entendiéndose que su alcance se limitará a los delitos intencionales que tengan consecuencias fatales u otras consecuencias extremadamente graves; B) Toda persona condenada a muerte tendrá derecho a apelar ante un tribunal de 
Los Estados deben respetar rigurosamente las garantías judiciales del inculpado. Si esta observancia es inexcusable en todos los casos, lo es más todavía cuando se halla en riesgo la vida humana. ${ }^{159}$ Existe entonces la necesidad de garantizar con rigor el debido proceso $^{160}$ en casos de pena de muerte. ${ }^{161}$

Debido a la naturaleza excepcionalmente seria e irreversible de la pena de muerte, su imposición o aplicación está sujeta a ciertos requisitos procesales, que limitan el poder punitivo del Estado y cuyo cumplimiento debe ser estrictamente observado. La obligación del Estado de respetar y garantizar el derecho a las garantías judiciales es más exigente y amplia en aquellos procesos que puedan culminar en la pena de muerte. ${ }^{162}$ Una violación del derecho a las garantías judiciales del acusado en un caso de pena de muerte,

jurisdicción superior y deberán tomarse medidas para garantizar que esas apelaciones sean obligatorias; C) Toda persona condenada a muerte tendrá derecho a solicitar el indulto o la conmutación de la pena; en todos los casos de pena capital se podrá conceder el indulto o la conmutación de la pena. Véase http://www2.ohchr.org/spanish/law/condenados.htm.

${ }^{159}$ Cfr. El derecho a la información sobre la asistencia consular en el marco de las garantías del debido proceso legal, Opinión Consultiva OC-16/99 emitida el $1^{\circ}$ de octubre de 1999, Serie A, núm. 16, párrafos 119, 135 y 136; Caso Hilaire, Constantine, Benjamín y otros, cit., párrafos 145-147 y voto concurrente del juez García Ramírez en este caso, párrafo 19, y Caso Fermin Ramirez, cit., párrafos 78 y 79.

${ }^{160}$ Según la Corte Interamericana, el debido proceso es el "conjunto de requisitos que deben observarse en las instancias procesales a efecto de que las personas estén en condiciones de defender adecuadamente sus derechos ante cualquier (...) acto del Estado que pueda afectarlos". Condición Jurídica y Derechos de los Migrantes Indocumentados, Opinión Consultiva OC-18/03, 17 de septiembre de 2003, Serie A, núm. 18, párrafo 123. Para que exista debido proceso, "es preciso que un justiciable pueda hacer valer sus derechos y defender sus intereses en forma efectiva y en condiciones de igualdad con otros justiciables". El derecho a la información sobre la asistencia consular, cit., párrafo 117.

${ }^{161}$ Voto concurrente razonado del juez García Ramírez al Caso Fermín Ramírez, Sentencia del 18 de junio de 2005, párrafos 10 y 11, y voto concurrente razonado del juez Sergio García Ramírez al Caso Dacosta Cadogan del 24 de septiembre de 2009, párrafo 11.

${ }^{162}$ Por lo que el estricto cumplimiento de ciertas garantías procesales es esencial para evaluar si la pena de muerte se ha aplicado de manera arbitraria. Cfr. Restricciones a la Pena de Muerte (arts. 4.2 y 4.4 Convención Americana sobre Derechos Humanos), Opinión Consultiva OC-3/83, 8 de septiembre de 1983, Serie A, núm. 3, párrafo 55, y Caso Fermín Ramírez, cit., párrafos 78-79; Caso Boyce y otros, Sentencia 20 de noviembre de 2007 (Excepción Preliminar, Fondo, Reparaciones y Costas), Serie C, núm. 169, párrafos 50 y 59, y Caso Dacosta Cadogan, Sentencia del 24 de septiembre de 2009 (Fondo, Reparaciones y Costas), Serie C, núm. 204, párrafos 84 y 85. 
tal como la de no proveerle medios razonables y adecuados para su defensa, podría acarrear una privación arbitraria del derecho a la vida. ${ }^{163}$

Para fortalecer la observancia de las garantías del individuo en el curso del proceso, la Corte Interamericana ha dispuesto que corresponde "al juez adoptar una posición más activa para asegurar que se adopt(en) todas las medidas necesarias para velar por el respeto de las garantías judiciales". ${ }^{164}$

La Corte Interamericana también ha señalado que pudiera incurrirse en violación a las garantías judiciales de los imputados de delito sancionado con pena de muerte cuando no se efectúa, durante el proceso penal, una "evaluación detallada" sobre su salud mental ${ }^{165}$ o no se brinda al extranjero información en torno al derecho que tiene de recibir asistencia consular. ${ }^{166}$ Estas omisiones violatorias de las garantías judiciales pueden determinar que la violación de la vida resulte arbitraria.

En el caso concreto de las personas condenadas a pena de muerte, la Corte Interamericana, retomando la posición de la Corte Europea, observa que el "fenómeno del corredor de la muerte" es un trato cruel, inhumano y degradante constituido por un periodo de detención prolongado en espera y previo a la ejecución, durante el cual se sufre de angustia mental además de otras circunstancias a las que el acusado es expuesto. ${ }^{167}$

Respecto de las condiciones generales de detención, la Corte ha especificado que toda persona privada de libertad tiene derecho a vivir en situación de detención compatible con su dignidad personal. ${ }^{168}$

En el caso concreto de las personas condenadas a pena de muerte, la Corte Interamericana, retomando la posición de la Corte Europea, observa que el "fenómeno del corredor de la muerte" es un trato cruel, inhumano y degradante constituido por un periodo de detención prolongado en espera

${ }^{163}$ Caso Dacosta Cadogan, cit., párrafo 89

${ }^{164}$ Caso Dacosta Cadogan, cit., párrafo 83. En esta hipótesis el trastorno mental al tiempo de cometer el delito puede implicar la exclusión de la pena capital.

${ }^{165}$ Cfr. El derecho a la información sobre la asistencia consular..., cit., párrafos 119 , 135 y 136.

${ }^{166}$ Cfr. Caso Hilaire, Constantine, Benjamín y otros, cit., párrafo 167.

${ }^{167}$ Cfr. Caso Hilaire, Constantine, Benjamín y otros, cit., párrafo 168; Caso Tibi, cit., párrafo 150; Caso Lori Berenson Mejía, cit., párrafo 102; Caso Caesar, Sentencia del 11 de marzo de 2005 (Fondo, Reparaciones y Costas), Serie C, núm. 123, párrafo 97; Caso Fermín Ramírez, cit., párrafo 118; Caso Raxcacó Reyes, Sentencia del 15 de septiembre de 2005 (Fondo, Reparaciones y Costas), Serie C, núm. 133, párrafos 73-82 y 95; Caso García Asto y Ramírez Rojas, cit., párrafo 221, y Caso López Álvarez, cit., párrafos 105 y 106.

${ }^{168}$ Cfr. Caso Hilaire, Constantine, Benjamín y otros, cit., párrafo 167. 
y previo a la ejecución, durante el cual se sufre de angustia mental además de otras circunstancias a las que el acusado es expuesto. ${ }^{169}$

\section{Aplicación de apremios y penas corporales}

Diversos instrumentos internacionales prohíben específicamente la tortura, ${ }^{170}$ así como otros tratos crueles, inhumanos o degradantes, que se hallan excluidos, por supuesto, por medio de disposiciones generales que reprueban los apremios ilícitos que lesionan el derecho a la integridad personal. La proscripción de esas medidas pertenece al dominio del jus cogens, como ha sostenido la Corte Interamericana. ${ }^{171}$ Dicha prohibición es absoluta e inderogable, aun en las circunstancias más difíciles, tales como guerra, amenaza de guerra, lucha contra el terrorismo y cualesquiera otros delitos, estado de sitio o de emergencia, conmoción o conflicto interior, suspensión de garantías constitucionales, inestabilidad política interna $u$ otras emergencias o calamidades públicas. ${ }^{172}$

Colinda con esta cuestión el empleo de penas corporales, que va de salida en la historia de las sanciones, pero se conserva en algunas leyes vigentes en el área americana; tales penas están cubiertas, pues, por el manto de la legalidad formal — no así de la legalidad material—, tanto en lo que respecta a su imposición por parte de los tribunales, como consecuencia de la comisión de ciertos delitos, como en lo que atañe a su ejecución.

169 Entre ellos, la Declaración sobre la Protección de Todas las Personas contra la Tortura y otros Tratos o Penas Crueles, Inhumanos o Degradantes (9 de diciembre de 1975), la Convención de las Naciones Unidas contra la Tortura y otros Tratos Crueles, Inhumanos y Degradantes (10 de diciembre de 1984) y la Convención Interamericana para Prevenir y Sancionar la Tortura (9 de diciembre de 1985).

${ }^{170}$ Cfr. Caso Cantoral Benavides, cit., párrafo 95; Caso Maritza Urrutia, Sentencia del 27 de noviembre de 2003 (Fondo, Reparaciones y Costas), Serie C, núm. 103, párrafo 92; Caso Hermanos Gómez Paquiyauri, cit., párrafo 111; Caso Caesar, cit., párrafos 59 y 100; Caso de la Masacre de la Rochela, Sentencia del 11 de de mayo de 2007 (Fondo, Reparaciones y Costas) Serie C, núm. 163, párrafo 132; Caso Bueno Alves, Sentencia del 11 de mayo de 2007 (Fondo, Reparaciones y Costas) Serie C, núm. 164, párrafos 76 y 77, y Caso Bayarri, Sentencia del 30 de octubre de 2008 (Excepción Preliminar, Fondo, Reparaciones y Costas) Serie C, núm. 187, párrafo 81.

${ }^{171}$ Cfr. Caso Maritza Urrutia, cit., párrafo 92; Caso Tibi, cit., párrafo 143; Caso De la Cruz Flores, cit, párrafo 125; Caso Lori Berenson Mejía, cit, párrafo 100.

${ }^{172}$ Cfr. Caso Caesar, cit, párrafos 57-79, 98 y 100. 
La Corte Interamericana se ha referido a la flagelación. Al hacerlo, ha reflexionado sobre la naturaleza de la medida y las características de su ejecución, desde la perspectiva de los derechos humanos, y ha entendido que ese castigo entraña una forma de tortura o trato cruel, inhumano o degradante. Corresponde, pues, a la categoría de las medidas estrictamente prohibidas por el derecho internacional de los derechos humanos. La Corte considera que las penas corporales de flagelación reflejan una "institucionalización de la violencia"; pese a estar permitidas por la ley y a ser ordenadas por las autoridades judiciales y ejecutadas por las autoridades penitenciarias, son incompatibles con la Convención. La flagelación constituye una forma de tortura y, en consecuencia, una violación per se del derecho al respeto de la integridad física, psíquica y mental. ${ }^{173}$ Por ende, un Estado parte en la Convención Americana está obligado — se habla de obligación erga omnes — ${ }^{174}$ a prescindir de medidas punitivas de este género.

\section{E. Legalidad en las medidas cautelares. Privación de la libertad}

Los límites al ejercicio de la autoridad que hemos mencionado se aplican, desde luego, a las medidas cautelares. Estas implican restricción legítima de derechos y libertades, legalmente prevista, para preservar la materia de un proceso y asegurar el buen desarrollo de éste. Puesto que se trata de restricciones a derechos, es preciso atenerse a los principios que gobiernan el sistema general de restricciones, a saber: fin legítimo, estipulación en la ley, necesidad, racionalidad — en función del objetivo procurado-, proporcionalidad, provisionalidad.

Estas exigencias derivan de la tensión existente $-\mathrm{y}$ difícilmente resoluble - entre la presunción de inocencia y la necesidad de asegurar la presencia del inculpado (presunto inocente, mientras no existe sentencia condenatoria) en el proceso. Tómese en cuenta que las medidas a las que

${ }^{173}$ Cfr. Caso Caesar, cit, párrafo 70 y voto del juez Sergio García Ramírez al Caso Raxcacó Reyes, sentencia del 15 de septiembre de 2005, párrafo 22, en donde afirma: "No se ha podido afirmar que la proscripción de la muerte punitiva ya constituye un postulado del derecho imperativo, es decir, jus cogens internacional, que trae consigo obligaciones erga omnes de los Estados, como lo es en cambio - paradójicamente- la exclusión terminante y absoluta de la tortura y de los tratos crueles, inhumanos o degradantes".

${ }^{174}$ Establece que "nadie puede ser privado de su libertad física, salvo por las causas y condiciones fijadas de antemano por las Constituciones políticas de los Estados partes o por las leyes dictadas conforme a ellas". 
ahora nos referimos poseen naturaleza exclusivamente cautelar o precautoria - en el marco de un procedimiento, y atentas a los requerimientos de éste-, no sancionatoria. Esto ciñe estrictamente los supuestos y las características de las medidas.

Entre los instrumentos cautelares más relevantes, de empleo frecuente - excesivo, en ocasiones - figuran diversas hipótesis de detención: la captura breve y la prisión preventiva, ambas sujetas a la observancia estricta del principio de legalidad, material y formal. El régimen de las medidas cautelares ofrece gran interés desde la perspectiva de la legalidad.

Los párrafos $2^{175}$ y $3^{176}$ del artículo 7o. de la Convención Americana prohíben, respectivamente, las detenciones ilegales y las detenciones arbitrarias. En el examen del primer precepto mencionado, la Corte distinguió dos aspectos de la cuestión: privación de la libertad personal por las causas y en los casos o circunstancias expresamente tipificadas en la ley (exigencia a la que se ha calificado como "aspecto material": fundamento sustantivo de la detención); y estricta sujeción a los procedimientos objetivamente definidos por aquélla para los fines de una detención (requerimiento al que se ha llamado "aspecto formal": base adjetiva de la detención).

La detención se funda en la existencia de indicios que permitan suponer, razonablemente, que se ha incurrido en un delito y que cierta persona, a la que se pretende detener, ha participado en la comisión de aquél. Si no se presentan ambos supuestos, la detención devendrá arbitraria.

El tribunal consideró que el artículo 7.2 proscribe, entre otros extremos, la detención o encarcelamiento por causas y métodos que - aún calificados de legales - puedan reputarse incompatibles con el respeto a los derechos fundamentales del individuo, en virtud de ser irrazonables, imprevisibles o carentes de proporcionalidad. ${ }^{177}$

${ }^{175}$ Indica que "nadie puede ser sometido a detención o encarcelamiento arbitrarios".

${ }^{176}$ Cfr. Caso Gangaram Panday, Sentencia del 21 de enero de 1994 (Fondo, Reparaciones y Costas), Serie C, núm. 16, párrafo 47; Caso Cesti Hurtado, Sentencia del 29 de septiembre de 1999 (Fondo), Serie C, núm. 56, párrafo 140; Caso Durand y Ugarte, cit., párrafo 85; Caso Bámaca Velásquez, cit., párrafo 139; Caso Juan Humberto Sánchez, cit., párrafo 78; Caso Maritza Urrutia, cit., párrafo 65; Caso de los Hermanos Gómez Paquiyauri, cit., párrafos 83 y 89; Caso Tibi, cit., párrafo 98, y Caso Acosta Calderón, Sentencia del 24 de junio de 2005 (Fondo, Reparaciones y Costas), Serie C, núm. 129, párrafo 57.

${ }^{177}$ Cfr. Esta temática es abordada extensamente en Bigliani, Paola y Bovino, Alberto, Encarcelamiento preventivo y estándares del sistema interamericano, Editores del Puerto, Buenos Aires, 2008. 
Se distingue, pues, entre detención ilegal y detención arbitraria. La primera se presenta cuando la privación de libertad se practica sin que existan los supuestos previstos por la norma para ese fin. La detención arbitraria puede tener sustento legal, pero carece de otras condiciones de legitimación: medios razonables, proporcionalidad, por ejemplo: es legal, pero ilegítima. ${ }^{178}$

En suma, no se satisfacen los mencionados requerimientos materiales y formales de la detención, y por ello se vulnera la legalidad en lo que toca a esta medida cautelar, cuando se detiene a una persona sin que se configuren las causas y condiciones establecidas para ello por la Constitución (que debieran ser compatibles con la Convención Americana), o no se pone al detenido a disposición de la autoridad judicial competente dentro del plazo previsto por la misma ley fundamental. ${ }^{179}$

Asimismo, es indispensable que la orden de captura provenga de una autoridad legalmente facultada para emitirla, salvo en caso de flagrante delito. ${ }^{180}$

Considerando su naturaleza y los propósitos a los que atiende, la medida cautelar debe tener corta duración: el tiempo más breve posible. Aquí viene a cuentas el "plazo razonable", en la inteligencia de que el artículo 7o. de la CADH se refiere a dicho plazo con respecto a la detención y la prisión preventiva (medidas cautelares) ${ }^{181}$ y el artículo 8 concierne a la duración del proceso. ${ }^{182}$ En lo que toca al plazo, hay que tomar en cuenta tanto la subsistencia o la desaparición de las condiciones que determinaron la medida, como el tiempo transcurrido. Si aquéllas cesan, la medida debe concluir, cualquiera que sea el tiempo transcurrido; si el periodo de detención es a todas luces excesivo, también debe cesar la detención, aunque subsistan las condiciones que la determinaron. Es preciso que la autoridad que ordena la

${ }^{178}$ Cfr. Caso de los "Niños de la Calle" (Villagrán Morales y otros), Sentencia del 19 de noviembre de 1999 (Fondo), Serie C, núm. 63, párrafos 132-134.

${ }^{179}$ Cfr. Caso García Asto y Ramírez Rojas, párrafos 106 y 108; Caso López Álvarez, cit, párrafo 67, y Caso Servellón García, cit., párrafos 88-90.

${ }^{180}$ Cfr. Caso Bayarri, cit., párrafo 70.

${ }^{181}$ Cfr. Caso García Prieto y otros, Sentencia del 20 de Noviembre de 2007 (Excepciones Preliminares, Fondo, Reparaciones y Costas) Serie No. 168, párrafo 115; Caso Salvador Chiriboga, Sentencia del 6 de mayo de 2008 (Excepción Preliminar y Fondo), Serie C, núm. 179, párrafo 59; Caso Heliodoro Portugal, cit., párrafos 148 y 149; Caso Valle Jaramillo y otros, Sentencia del 27 de noviembre de 2008 (Fondo, Reparaciones y Costas), Serie C, núm. 192, párrafo 154; Caso Bayarri, cit., párrafo 105, y Caso Ticona, cit., párrafo 79 .

${ }^{182}$ Caso Vélez Loor, cit., párrafo 108. 
medida verifique sistemáticamente la pertinencia de ésta y disponga lo que resulte procedente: conservación, modificación, conclusión.

Por otra parte, respecto a los derechos de un migrante irregular detenido en el país de destino, se ha establecido que "la legislación interna debe asegurar que el funcionario (administrativo) autorizado por la ley para ejercer funciones jurisdiccionales cumpla con las características de imparcialidad e independencia que deben regir a todo órgano encargado de determinar derechos y obligaciones de las personas" ${ }^{183}$. Además, la revisión de la detención por parte de un juez o tribunal constituye un requisito fundamental para garantizar un control y escrutinio adecuados de los actos de la administración que afectan derechos fundamentales.

\section{CONCLUSIONES}

La revisión que se ha realizado en las páginas anteriores permite corroborar la hipótesis y la tesis que manejamos en el apartado I de este trabajo. La jurisprudencia de la Corte Interamericana de Derechos Humanos, concentrada en temas de legalidad como principio tutelar de los derechos y libertades del individuo, ha insistido en la vigencia de ese principio y afianzado con fuerza sus conexiones con la tutela del ser humano y el régimen democrático.

Esto se ha visto tanto en el orden general de los derechos humanos y la más amplia actividad del Estado - que no es el asunto central de este trabajo-, como en el régimen de la persecución penal, cuyas vicisitudes y particularidades quedan de manifiesto en las sentencias del Tribunal interamericano.

Queda establecido que los imperativos de seguridad jurídica inherentes al principio de legalidad no pugnan con la defensa del Estado y la preservación de la paz pública y el desarrollo social. El mismo régimen de legalidad afirmado por la jurisprudencia supone esa tutela social, pero rechaza que se procure o realice a costa de los derechos humanos, removiendo el Estado de derecho en aras — supuestamente- del bien común o la seguridad colectiva. La Corte Interamericana se ha pronunciado frecuentemente sobre el alcance de la actuación penal del Estado, el límite que impone la dignidad 
humana y los cauces y características para la aplicación de la ley punitiva y el uso legítimo de la fuerza, en sus diversas expresiones.

En este marco de reflexiones y decisiones se ha puesto énfasis - explícitamente- en el denominado derecho penal mínimo, característico del Estado democrático. Este concepto acerca del sistema penal preside todas las actuaciones - legislativas, ejecutivas y jurisdiccionales - en materia punitiva. A su amparo, la Corte Interamericana ha revisado las disposiciones y las prácticas penales. Entre otras aplicaciones del mismo concepto figura la opción por el derecho penal de conducta y la exclusión de nociones que pugnan con él, como la peligrosidad incorporada en la formulación de tipos y la sanción de delitos. El pronunciamiento de la Corte fue recogido por tribunales nacionales, como se indica en este trabajo.

La Corte Interamericana ha considerado detalladamente la potestad punitiva del Estado y la formulación de tipos penales. En relación con lo primero, ha puntualizado que el Estado no puede considerar delictuosas "cualesquiera conductas", por medio de la inclusión de tipos en el ordenamiento penal. Debe tomar en cuenta la naturaleza misma de esos comportamientos. En este sentido, se reprueba la penalización de conductas naturalmente legítimas (acto médico, por ejemplo). En suma, la jurisprudencia considera la distancia que media entre legalidad y legitimidad y reclama la coincidencia de ambas exigencias a la hora de formular los tipos penales y las sanciones correspondientes.

Igualmente, el Estado debe considerar la diversa gravedad de hechos que pudieran parecer iguales - privación de la vida, por ejemplo-, pero involucran elementos que obligan a establecer distinciones a propósito de los bienes jurídicos afectados, la culpabilidad del agente, los medios empleados, las circunstancias de comisión, etcétera. La Corte rechazó incriminaciones indebidas y exigió, por otra parte, la tipificación de ciertas conductas en los términos requeridos por el derecho internacional de los derechos humanos, como son la tortura y la desaparición forzada de personas.

En la misma línea de ideas, el Tribunal interamericano se ha referido a la técnica de tipificación — vinculada al régimen de garantías-, y excluido la presencia de tipos "a modo" para "facilitar" persecuciones heterodoxas, modificar penas a conveniencia y alterar la jurisdicción natural de los tribunales.

Un aspecto relevante de la jurisprudencia interamericana es el relativo al empleo de la fuerza - acerca de la cual existen criterios puntuales, basados en sendos principios limitantes de la represión penal — y al uso de medidas 
cautelares, que plantean problemas específicos en el ámbito penal, tomando en cuenta el carácter de los derechos afectados y la severidad de la afectación. Es importante la jurisprudencia de la Corte acerca de la detención y la prisión preventiva, medidas gobernadas —en los términos requeridos por la jurisprudencia del Tribunal - por principios de inexcusable observancia: a la cabeza de ellos, legalidad; asimismo, necesidad, congruencia, racionalidad, proporcionalidad, excepcionalidad, temporalidad.

Así, al ocuparse del principio de legalidad, la jurisdicción interamericana ha contribuido a esclarecer los límites de la acción u omisión estatal y ha dado pautas para el arraigo de dicho principio en el ámbito doméstico a fin de mejorar y extender la garantía de los derechos humanos. 